\title{
ARTICLES
}

\section{The Inherent Irrationality of Judgment Proofing}

\author{
Steven L. Schwarcz*
}

\begin{abstract}
In recent articles in the Yale Law Journal and the Stanford Law Review, Professor Lynn M. LoPucki has sparked much academic discussion arguing that recent developments in corporate law have led to an erosion in the system of corporate liability, such that it might one day prove impotent. LoPucki has argued that transactions such as asset securitizations, sale-leasebacks, and corporate structures in which liabilities are placed in asset-poor subsidiaries are driving this change. One early critic to the LoPucki thesis, Professor James $J$. White, has argued that empirical data show no evidence of increasing use of judgment proofing techniques. In this article, Professor Steven L. Schwarcz joins this debate, arguing that an economic analysis of these transactions suggests that widespread use of these judgment proofing techniques is unlikely. $A$ key distinction in the analysis, Schwarcz argues, is between arm's length and non-arm's length transactions. Arm's length transactions are unlikely to lead to judgment proofing because corporations will receive value-often cash-for the assets they sell. It is only by paying out this value in dividends that a corporation begins to judgment-proof itself. The theoretical possibility to take value away from future involuntary creditors through such transactions will rarely be realized because of the costs-taxes, negative publicity, personal and criminal liability-of entering into such agreements. By contrast, in non-arm's length transactions, corporate owners do have the incentive to create judgment-proof structures. However, these structures are not innovative, and they will continue to be well-regulated ex post by existing legal doctrines in bankruptcy, corporate law, tort law, and criminal law. Following this article are a response from Professor Lynn LoPucki, a comment by Professor Charles Mooney and a brief rejoinder from Professor Schwarcz.
\end{abstract}

* Professor of Law, Duke University School of Law, and Faculty Director, Duke University Global Capital Markets Center. E-mail: schwarcz@law.duke.edu. The author thanks Bernie Black, Paul Carrington, Jesse Fried, Elihu Inselbuch, Ken Klee, Lynn LoPucki, Gerry Lynch, Ron Mann, Steve Nickles, Peter Pantaleo, Eric Posner, Bob Rasmussen, Stephen Scher, Daniel Schwarcz, Paul Shupack, David Skeel, Tom Ulen, Laura Underkuffler, Todd Zywicki, and the participants in faculty workshops at the University of Pennsylvania (School of Law), Duke University (Fuqua School of Business), and Wake Forest University (School of Law and Babcock School of Management) for helpful comments on drafts of this article. The author also thanks William Boyer, Lyle Fuller, Thomas Loeser, and Eric Schupper for excellent research assistance. 


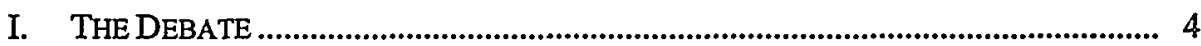

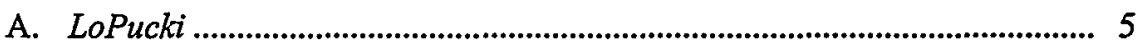

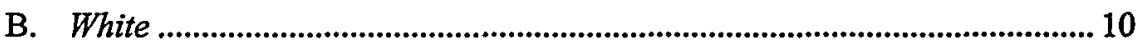

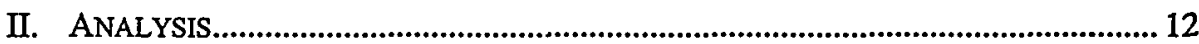

A. The Structuring of Arm's Length Business Transactions Should Not Give Rise to Judgment Proofing............................................................. 12

B. Arm's Length Business Transactions Are Unlikely to Take Advantage of the Value That Judgment Proofing Would Wrest from Future Involuntary Creditors.

C. The Structuring of Non-Arm's Length Business Transactions Is More Likely to Give Rise to Judgment Proofing .

D. Regulation of Judgment Proofing Under Existing Law..................................32

E. Is Non-Arm's Length Judgment Proofing Adequately Regulated by Law?

Liability is "one of only two principal means by which governments enforce law."' Yet recent articles in the Yale Law. Journal and the Stanford Law Review assert that liability is dying: "The system by which money judgments are enforced is beginning to fail. The immediate cause is the deployment of legal structures that render potential defendants judgment proof' by bifurcating the ownership of assets from the liabilities associated with operating those assets in a business. 2 These bifurcated structures are made possible, the argument goes, by computer technology which reduces the costs of record keeping. ${ }^{3}$ As a result, business "[j]udgment-proofing strategies have become cheaper and easier to execute"4 and purportedly are becoming more pervasive: "Some large businesses now employ [such judgment-proofing strategies] and market forces are driving their competitors to

1. Lynn M. LoPucki, The Death of Liability, 106 YALE L.J. 1, 3 (1996) [hereinafter Death of Liability] (observing that governments enforce law through incarceration for crimes and liability for civil wrongs).

2. Id. at 4. LoPucki observes that the legal system is being "manipulated by potential defendants to create judgment-proof structures." Id. By "judgment proof," I mean that creditors are losing the practical ability, as opposed to the legal right, to enforce their claims. Accord Lynn M. LoPucki, The Essential Structure of Judgment Proofing, 51 STAN. L. REV. 147, 149 (1998) [hereinafter Essential Structure] ("To own no assets is to be judgment-proof."). I include in this definition what LoPucki refers to as "soft" judgment proofing: merely limiting as opposed to completely denying liability. See Lynn M. LoPucki, Virtual Judgment Proofing: A Rejoinder, 107 YALE L.J. 1413, 1421 (1998) [hereinafter Virtual Judgment Proofing]. Thus, a strategy that denies a creditor recovery of a portion of its claim would be deemed to be judgment proofing.

3. See Death of Liability, supra note 1, at 47 (arguing that computerized record keeping now makes it feasible to maintain complex corporate judgment proof structures).

4. Id. at 5 . 
do the same. The social norms that prohibit their use among reputable businesses have begun to erode [and] the process may well be irreversible."'5

This article attempts to refute these assertions. First, I demonstrate that none of the examples put forth in the scholarship stands for the proposition claimed-that innovative business transactions give rise to judgment proofing. Then I show that by focusing on the structuring of business transactions, the scholarship obscures the conceptual divide between arm's length business transactions intended for judgment proofing, and non-arm's length judgment proofing structures. ${ }^{6}$ Yet the different motivations, perspectives, and costs inherent in each have crucial ramifications for the analysis.

In an arm's length judgment proofing transaction, each company will seek independent gain. Therefore the structuring of an arm's length business transaction, no matter how innovative, is unlikely to result in judgment proofing because no company will give up value without demanding equivalent value in return. It is, nonetheless, theoretically possible that unrelated companies could enter into arm's length judgment proofing transactions to take value from future involuntary creditors. I argue, however, that those transactions are unlikely to occur because, from the perspective of the company needed to assist the judgment proofing, potential costs may well exceed the company's benefits.

In a non-arm's length structure, on the other hand, the judgment proofing transaction takes place between related parties. Judgment proofing then is more likely than in an arm's length transaction because its benefits need only exceed its costs from the perspective of the controlling company. Non-arm's length judgment proofing structures, however, are not innovative and have long been regulated by law, which imposes costs that appear to outweigh any potential benefits.

The importance of distinguishing between arm's length and non-arm's length judgment proofing is not limited, however, to the different economic treatment of those transactions. ${ }^{7}$ Social psychology accentuates the distinc-

\section{Id.}

6. By arm's length, I mean transactions between two or more companies in which each company is attempting to maximize the value it will receive from the transaction. Transactions between unrelated companies therefore would be expected to be arm's length. $C f$. DICTIONARY OF FINANCE AND INVESTMENT TERMS 19 (2d ed. 1987) (defining "arm's length transaction" as one "that is conducted as though the parties were unrelated, thus avoiding any semblance of conflict of interest"). By non-arm's length, I mean transactions in which one or more of the companies is not seeking to maximize the value it will receive from the transaction. Relationships between related companies may or may not be arm's length. See notes 145-146 infra and accompanying text (discussing that whereas unrelated companies try to maximize the value each will receive from a transaction, related companies may want to maximize their aggregate corporate wealth, thereby making judgment proofing easier).

7. That distinction would be interesting but not necessarily compelling since, in each case, the economic result would be the same: The costs of judgment proofing appear to exceed the value taken from involuntary creditors. 
tion. Professors Jolls, Sunstein, and Thaler recently noted that "[ $[t]$ raditional law and economics is largely based on the standard assumptions of neoclassical economics. These assumptions are sometimes useful but often false. People display bounded rationality ...."8 By applying bounded rationality to the economics of judgment proofing, 9 I find that, in an arm's length transaction, the costs of judgment proofing are magnified because the parties will be risk averse. In a non-arm's length judgment proofing, however, those costs are minimized because the parties are more likely to take risks. Therefore theory alone cannot be used to predict the spread of non-arm's length judgment proofing transactions. Empirical data confirm, however, that nonarm's length judgment proofing is unlikely to increase in the future.

I conclude that existing constraints on judgment proofing are already adequate, and the law is likely to evolve additional restrictions as necessary. Accordingly, there is no need to impose regulatory responses. Indeed, to do so could indiscriminately restrict the value creation that comes with business and financial innovation.

To provide a context for my analysis, I begin by reviewing the current scholarly debate.

\section{THE DEBATE}

The debate presently centers on the work of two prominent scholars, Lynn LoPucki, the A. Robert Noll Professor at Cornell Law School, and James J. White, the Robert A. Sullivan Professor at the University of Michigan Law School. The former argues that liability is dying, while the latter counters that assertion. My analysis parallels the work of these scholars in two ways: It focuses on business judgment proofing strategies ${ }^{10}$ and meas-

8. Christine Jolls, Cass R. Sunstein \& Richard Thaler, A Behavioral Approach to Law and Economics, 50 STAN. L. REV. 1471, 1545 (1998) (arguing for tempering the simple maximizing model of economics with a psychological treatment). See generally Donald C. Langevoort, Organized Illusions: A Behavioral Theory of Why Corporations Mislead Stock Market Investors (and Cause Other Social Harms), 146 U. PA. L. REV. 101 (1997) (using organizational psychology to explain why corporations irrationally conceal information from the market); Steven L. Schwarcz, Introduction: Is Law an Autonomous Discipline?, 21 HARV. J.L. \& PUB. POL'Y 85 (1997) (arguing for the application of social psychology to law and economics).

9. An approach that generally can be referred to as behavioral economics. See Jolls et al., supra note 8, at 1474 ("behavioral economics allows [one] to model and predict behavior relevant to law with the tools of traditional economic analysis, but with more accurate assumptions about human behavior....").

10. See generally Death of Liability, supra note 1 (discussing strategies for business judgment proofing); James J. White, Corporate Judgment Proofing: A Response to Lynn LoPucki's The Death of Liability, 107 YALE L.J. 1363 (1998) (concluding that "Professor LoPucki is concemed principally, if not exclusively, with the tort and statutory liability of public commercial firms" and that "LoPucki should be concerned principally with injuries caused by business enterprises, not with torts by individuals. It is a rare individual [subject to the special cases of personal automobile 
ures the impact of these strategies by their effect on future involuntary creditors such as tort creditors and holders of statutorily imposed claims who cannot protect themselves ${ }^{11}$ (as opposed to contract creditors who voluntarily extend credit and therefore can protect themselves by demanding financial information about the company and, if necessary, requiring guaranties or collateral12).

\section{A. LoPucki}

Professor LoPucki contends that two basic types of judgment-proofing strategies are relevant to business debtors: secured debt strategies, in which unsecured claims of involuntary creditors are subordinated to secured claims; 13 and third-party ownership strategies, in which ownership of valuable assets is transferred to third parties. ${ }^{14}$ Secured debt strategies are "so deep-rooted in culture that they are virtually impossible to change."15 Thirdparty ownership, however, represents a potentially damaging form of judgment proofing that could be susceptible to regulation.

liability and physician liability] who can cause enough personal injury or property damage to make it worth his while to escape liability.").

11. See Death of Liability, supra note 1, at 7 (noting that only tort and statutorily imposed liability are impacted); White, supra note 10, at 1365 (noting that the victims are not those with contract claims).

12. See White, supra note 10 , at 1365 (noting that "Professor LoPucki recognizes that contract creditors-creditors ranging from banks to finance companies to suppliers-can and will bargain for protection").

13. See Death of Liability, supra note 1, at 14-19. LoPucki asserts that secured debt strategies are "employed primarily by small, relatively uncreditworthy businesses, whose lenders insist on security interests.... The debtor becomes judgment proof by incurring secured debts in amounts exceeding the liquidation values of the debtor's properties. Money judgments thereafter enforced against the debtor's properties are subordinate to the secured debt." Id. at 14 (footnote omitted). A problem with this assertion is that it fails to take into account that the debtor receives new money for the loan, and that new money (unless wasted or misused by the debtor) creates value that will be available to pay unsecured creditors. $C f$. notes 64-77 infra and accompanying text (discussing other analyses that fail to account for the new money).

14. See Death of Liability, supra note 1, at 19-30. He also contends that, in a non-business context, two additional types of judgment proofing strategies are possible: exemption and foreign haven. See id. at 30-38. The exemption strategy depends on state and federal laws that "exempt various kinds of property from procedures to enforce judgments for money damages." Id. at 30-31. The foreign haven strategy focuses on an individual debtor's transfer of her personal assets to a foreign jurisdiction. See id. at 32. Creditors therefore must sue in the foreign jurisdiction and, if that jurisdiction will not enforce liability against the debtor's assets, the transfer bars recovery. See id. White agrees that LoPucki's categories of "exemption strategies and foreign haven strategies ... are not relevant to corporate liability." White, supra note 10 , at 1368.

15. Death of Liability, supra note 1 , at 4 . LoPucki indeed admits that a range of legal constructs, including not only secured debt but also shareholder limited liability, national sovereignty, and the ownership of property, are equally deep rooted in culture and therefore virtually impossible to change. See id. Cf. Steven L. Schwarcz, The Easy Case for the Priority of Secured Claims in Bankruptcy, 47 DUKE L.J. 425 (1997) [hereinafter Easy Case] (arguing that contrary to the goal of judgment proofing, secured credit actually increases the expected value of unsecured claims). 
He argues that there are two approaches to third-party ownership. In the first, the parent-subsidiary strategy, "the debtor isolates the most valuable assets of the business in an entity other than the one that conducts the liability-producing business activity."16 LoPucki describes a typical parentsubsidiary structure as follows:

[T] he company [Operations, Inc.] incorporates a subsidiary (Finance, Inc.), and retains ownership of all the stock. As Operations sells its products, it creates accounts receivable. Operations sells the accounts to Finance, and distributes any proceeds beyond its immediate cash needs to its shareholders [leaving Operations with minimal assets]. Finance pays for the accounts by borrowing on an unsecured basis from a bank. If Operations sells defective products and incurs liability, [the tort creditors' claims are subordinate to the bank's claim because the] bank claims the assets of Finance as an unsecured creditor while the [tort] creditors claim them as a shareholder."17

This "parent-subsidiary ownership strategy," he alleges, "is in wide use among the largest companies in America [and 1]imiting liability ... is the principal reason for" employing that strategy. ${ }^{18}$

The other approach to third-party ownership, LoPucki contends, is asset securitization, "by far the most rapidly growing segment of the U.S. credit markets." 19 In a securitization, a company transfers rights in incomeproducing assets 20 - such as accounts receivable, loans, or lease rentals-to a special purpose vehicle, or "SPV." The SPV, in turn, issues securities to capital market investors and uses the proceeds of the issuance to pay for the assets. ${ }^{21}$ The investors, who are repaid from collections of the assets, buy the securities based on their assessments of the value of the assets. Because the SPV (and no longer the company) owns the assets, their investment decisions often can be made without concern for the company's financial condition. Thus, viable companies that otherwise cannot obtain financing, because of a weakened financial condition, now can do so. Even companies that other-

16. Death of Liability, supra note 1 , at 20 .

17. Id. Technically, of course, the tort creditors claim such assets not as shareholders but as creditors of the shareholder.

18. Id. at 21. But see notes 66-71 infra and accompanying text (arguing that although the parent-subsidiary ownership strategy is widespread, limiting liability is not the principal reason for using it).

19. Death of Liability, supra note 1 , at 24 .

20. Income-producing assets are sometimes referred to as financial assets.

21. See generally TAMAR FRANKEL, SECURTIZATION: STRUCtURED FINANCING, FNANCIAL ASSETS POOLS, AND ASSET-BACKED SECURITIES (1991 \& Supp. 1999); STEVEN L. SCHWARCZ, STRUCTURED FINANCE: A GUIDE TO THE PRINCIPLES OF ASSET SECURITIZATION (2d ed. 1993) [hereinafter SECURITIZATION]; Christopher W. Frost, Asset Securitization and Corporate Risk Allocation, 72 TUL. L. REV. 101 (1997) (examining why asset securitization has become a popular financial device); Claire A. Hill, Securitization: A Low-Cost Sweetener for Lemons, 74 WASH. U. L.Q. 1061 (1996) (explaining the source of securitization's benefits); Steven L. Schwarcz, The Alchemy of Asset Securitization, 1 STAN. J.L. BUS. \& FIN. 133 (1994) (explaining the benefits of asset securitization) [hereinafter Alchemy]. 
wise could obtain financing now will be able to receive lower-cost capital market financing. 22

Whereas the parent-subsidiary structure is time honored, asset securitization is a relatively new phenomenon that has become widespread with the help of computers. ${ }^{23}$ LoPucki sees it as a fundamental shift in the way that companies deal with liability-a shift that has "enormous potential" for judgment proofing:

By selling any asset to a bankruptcy-remote entity and leasing it back, the debtor can transform it into an "income-producing" asset that can then be securitized....

Through asset securitization, a company potentially could divest itself of all of its assets, yet continue to use all of those assets in the continued operation of its business. To grasp the enormous potential, assume that, through a series of asset securitizations, Exxon Corporation disposes of all of its assets. As the cash from these transactions becomes available, Exxon distributes the cash to its shareholders in the form of dividends, leaving the company with neither assets nor liabilities. (I will refer to this judgment-proof Exxon as "Zero-Asset Exxon.") Because Exxon contracts to continue use of each asset even as Exxon sells it, the operations of Zero-Asset Exxon remain exactly as they were when it was a multibillion dollar company. But as a result of the asset-securitization transactions and the distribution of the proceeds, Zero-Asset Exxon is now judgment proof. 24

Accordingly, LoPucki warns, "[a]sset securitization may be the silver bullet capable of killing liability." 25

LoPucki next argues that existing constraints on judgment proofing, 26 as

22. Securitization has an increasingly international focus, in part because companies that wish to raise funds from the capital markets may not be located in countries with established capital markets. To access capital market funding, those companies will have to structure deals that cross their national borders. See Steven L. Schwarcz, The Universal Language of Cross-Border Finance, 8 DUKE J. COMP. \& INT'L L. 235, 236-37 (1998). To the extent securitization creates a problem of judgment proofing, the judgment proofing problem would be international and not merely domestic.

23. Joseph C. Shenker \& Anthony J. Colleta, Asset Securitization: Evolution, Current Issues and New Frontiers, 69 TEx. L. REV. 1369, 1370-71 (1991) (describing computers and other new technology as contributing factors to the explosive growth of securitization).

24. Death of Liability, supra note 1, at 25-26 (footnotes omitted). LoPucki sees all assets as transformable into income-producing assets that can be securitized. I later show, however, that there are significant practical limitations on the transformation of assets into income-producing assets and that, even given such transformation, asset securitization will not judgment-proof a company because the company receives cash proceeds equal to the amount of any assets transferred. I also show that the initial sale-leaseback transaction, and not a subsequent securitization, is the more relevant transaction for investigating judgment proofing, and that even a sale-leaseback transaction is not troublesome so long as the company, in this case Exxon, retains the sale proceeds.

25. Death of Liability, supra note 1 , at 30 .

26. He identifies five existing constraints. The first, which he calls self-immolation, is that shareholders of a company would oppose judgment proofing because the company's inability to pay claims would wipe out equity. Nonetheless, he argues that by externalizing liability and thereby enabling the company to borrow at a lower interest rate, judgment proofing increases, rather than 
well as radical reform responses, would be inadequate. 27 He therefore concludes that innovative third-party ownership structures, such as asset securitization and parent-subsidiary ownership, will kill business liability.28

lowers, the ex ante value of equity. See Death of Liability, supra note 1, at 40-42. Another constraint is the precarious position at judgment proof firms of managers who, if the firm incurs a significant liability, may lose their jobs. See id. at 42-43. He nevertheless contends that firms can overcome this constraint by paying managers a portion of the benefits of externalizing. See id. at 43. (I later discuss this constraint in the context of analyzing the agency costs of judgment proofing. See notes 109, 115-116 infra and accompanying text.) A third constraint is that few companies would find judgment proofing to be cost effective because the cost of judgment-proofing a business is high whereas the risk of significant liability is low. See Death of Liability, supra note 1, at 43-47. However, he counters that the cost of judgment proofing will decline "once other large companies break the ice," and then even large, established companies will consider judgment proofing strategies worth the expense and hassle. Id. at 44 (analogizing the situation to the reluctance of large companies to use bankruptcy reorganization in the $1970 \mathrm{~s}$, whereas now bankruptcy is an acceptable corporate tool). A fourth possible constraint is the legal and clerical costs of maintaining complex corporate judgment proof structures, but LoPucki counters that computerized record keeping now makes this feasible. See id. at 47-51. As for the final constraint, culture and politics, he concludes that "all hell would [not] break loose" if large companies were to make themselves judgment proof because, at least in the small business context, "[t]he company went bankrupt" is considered an adequate explanation for why tort claimants and other unsecured creditors often are not paid. See id. at 51-54. "[S]o long as the companies march into this new world [of judgment proofing] in tandem, each objecting that it is forced into its course of action by competitive pressures, it will be difficult for indignation to take hold." Id. at 54 (footnote omitted). (I later argue, however, that judgment proofing creates additional reputational cosis. See notes 109-114 infra and accompanying text.)

27. Several radical reform responses have been advanced. One response is to extend liability from property of the debtor to the debtor's shareholders, affiliates, and trading partners (and possibly even to those who provide the assets used in the debtor's business), thereby motivating those parties to contract among themselves to assure that the liability is paid, such as by compelling the corporation to purchase adequate liability insurance. See Death of Liability, supra note 1, at 55 (referring to the scholarly debate over whether shareholders should have liability for torts committed by their corporations if the corporation's assets are insufficient to satisfy its liabilities). Nonetheless, those parties would have little difficulty defeating unlimited liability. For example, it is impractical for tort claimants to identify shareholders who might be worth suing, and the lawsuit itself might not be cost effective, especially where the claim is small. See id. at 56-57 (noting that share ownership often is beneficially owned for individual investors who hold minute fractional interests). Investors also could shift to trust structures in which they would retain limited liability, see id. at 58-59, or they could purchase shares in U.S. corporations through foreign limited liability companies and thereby rely on foreign law to defeat liability. See id. at 59-61 (citing arguments advanced by Professor Joseph Grundfest). LoPucki additionally suggests, as a radical reform response, that subordinating secured creditor claims to involuntary claims would encourage secured creditors to monitor their debtors in order to limit their liability-generating activity. See id. at 61 . However, debtors then could use securitization to avoid becoming subject to monitoring because, he maintains, investors in the securitization transaction would be owners, not secured creditors, and therefore their claims would not be subject to subordination. See id. at 62 (noting that small businesses sometimes do this). Even conditioning the right to do business on demonstrating financial responsibility - such as by requiring minimum levels of liability insurance, surety bonds, or proof of solvency - would not prevent judgment proofing because many liability-generating occurrences, such as intentional torts, are not of an insurable nature. Making them insurable would create a moral hazard because the tortfeasor would no longer bear, and therefore would not be deterred by, the cost of its actions. See id. at 72. Moreover, experience in those parts of the economy where insurance is compulsory today shows "a sharp increase in the burden of regulation and a diminution of the effectiveness of liability insurance." Id. at 80.

28. See id. at 90 . 
LoPucki more recently has observed that:

all, or substantially all, judgment proofing has a single essential structure: a symbiotic relationship between two or more entities, in which one of the entities generates disproportionately high risks of liability and another owns a disproportionately high level of assets. Through the contract that unites them, the two entities allocate between them the gains from judgment proofing. ${ }^{29}$

This is not only a more generic way of describing the "third-party ownership" judgment proofing structures (asset securitization, sale-leaseback, and parent-subsidiary ownership) referred to in The Death of Liability ${ }^{30}$ but also describes such traditional forms of judgment proofing as leasing assets to an undercapitalized company.31 Because the "third-party ownership" structures ${ }^{32}$ describe representative judgment proofing transactions, I will refer to them as well as to the generic structure.

In these articles, LoPucki rarely distinguishes whether he is focusing on arm's length or non-arm's length transactions. His analysis, however, is broad enough to include both-his generic structure includes the example of a "symbiotic relationship that exists between truly independent owning and operating entities"33_-and his intention clearly was to focus on both. ${ }^{34} \mathrm{My}$

29. Essential Structure, supra note 2, at 149.

30. To understand why, recall that the third-party ownership strategy is comprised of two basic techniques-parent-subsidiary ownership and asset securitization-and that asset securitization is preceded by a sale-leaseback transaction in which ordinary assets are converted to incomeproducing assets. In the parent-subsidiary ownership technique, the parent-operating company incorporates a finance subsidiary which borrows money to purchase accounts receivable from the parent. The parent, in turn, pays the money to its shareholders in the form of dividends. Thus, the parent, which continues to operate its business, generates disproportionately high risks of liability based on its minimal net worth, while the finance subsidiary owns a disproportionately high level of assets (all of the accounts receivable). In the asset securitization (and sale-leaseback) technique, the operating company sells its assets to a separate entity, which leases those assets back. The operating company then pays the sale proceeds to its shareholders in the form of a dividend and continues to operate with the leased assets. Thus, the operating company generates disproportionately high risks of liability based on its failure to own assets, while the separate entity owns a disproportionately high level of assets (all of the assets).

31. Because this article focuses on whether innovative business transactions are causing judgment proofing, the issue of whether state corporation law imposes adequate capital requirements is beyond its scope. Nonetheless, I examine undercapitalization as one of a range of judgment proofing techniques.

32. That is, those structures described as such in Death of Liability, supra note 1. As LoPucki defines his "essential structure," however, it is merely another name for generic third-party ownership. For example, even leasing assets to an undercapitalized company could be referred to as thirdparty ownership by the lessor.

33. Essential Structure, supra note 2, at 155. He also uses an example of "cooperating entities [that] form independently of each other [and are] brought together by investment bankers or brokers to contract at arm's length." Id. at 156.

34. See Letter from Lynn M. LoPucki, A. Robert Noll Professor of Law, Cornell Law School, to Steven L. Schwarcz, Professor of Law, Duke University School of Law 2 (October 17, 1998) (on file with author) (confirming that intention). 
analysis also will cover both arm's length and non-arm's length judgment proofing.

\section{B. White}

In an empirical response, Professor White presents an empirical analysis intended to show that "the story Professor LoPucki tells is fictional." 35 Observing that the amount of secured debt as a percentage of a company's assets has not been increasing, ${ }^{36}$ White suggests that creditors are insufficiently concerned about judgment proofing to demand additional collateral. He also finds "there is no perceivable long-term trend [in the ratio of corporate assets to liabilities]. The medians for all data are remarkably constant, hovering near [an asset-to-liability ratio of] 1.75." 37 Thus, he believes, companies remain adequately capitalized.38 White additionally finds that, although "[b]uying liability insurance is inconsistent with judgment proofing," 39 the "data show no significant changes between 1981 and 1995" in the amount of liability insurance carried by companies. 40 Based on these findings, White concludes that "firms choose not to judgment proof themselves" and that "judgment proofing ... is unlikely ever to grow into a serious problem in the United States."41 In short, "[1]iability lives."42

Incongruously, White then cautions that it is presently impossible to prove or disprove whether judgment proofing will kill liability. ${ }^{43}$ White states that he has "uncovered no empirical evidence for the proposition that American firms, in general, have judgment proofed themselves or are judg-

35. White, supra note 10 , at 1364 .

36. His data indeed show that "[t]he number of companies with significant secured debt is declining, not rising." Id. at 1374.

37. Id. at 1376. But see note 261 infra (arguing that there are several ways that the asset-toliability ratio could be manipulated by a company).

38. See White, supra note 10 , at 1375.

39. Id. at 1380. White argues that if "businesses believe that they can render themselves judgment proof, it is a waste of money to purchase liability insurance." Id. at 1381. But see note 261 infra (arguing that even judgment proof companies will buy liability insurance so long as its cost is less than the cost of bankruptcy).

40. White, supra note 10 , at 1380 .

41. Id. at 1364. White collected his data from all of the companies in Standard \& Poor's Compustat database, a compilation of public financial data for publicly traded companies. See id. at 1370 \& n.38. Even though his data are limited to public companies, White "believe[s] that data from private companies would be no different [because a]lmost all of the barriers in [his article] to judgment proofing apply equally to public and private firms." Id. at 1412.

42. Id. at 1412 .

43. That claim is "as impossible to disprove as it is impossible to prove, for it involves not only an assumption of universal judgment proofing, but also an assumption that Chapter 11 will become cheaper and more efficient than it is now." Id. at 1383. Nonetheless, White argues that "it is as easy to imagine a world in which firms are judgment proof and Chapter 11 is more expensive and more stigmatizing than insurance." Id. 
ment proofing themselves," but nevertheless concludes that "the data do not foreclose the possibility that Professor LoPucki's claims will turn out to be correct in the future." 44

After setting forth his empirical arguments, 45 White considers potential barriers to judgment proofing. 46 His principal argument derives from the classic Modigliani-Miller thesis of finance theory: that the market value of any firm is independent of its capital structure. 47 Thus, the only way that equity holders can use judgment proofing to enhance their value is by taking value from creditors.48 That would be possible only if the creditors either are foolish, which he assumes they are not, or involuntary creditors who cannot bargain. ${ }^{49}$ I agree with this view, and therefore focus on how judgment proofing can be used to take value from involuntary creditors.

44. Id. at 1394. I later show, however, that Professor White's empirical data are valuable in analyzing non-arm's length judgment proofing. See notes 261-269 infra and accompanying text.

45. White uses a quasi-empirical argument to respond to the assertion that companies use a parent-subsidiary strategy for judgment proofing. The Compustat data show only consolidated financial information-that is, information on a parent and its subsidiaries is reported as if all such companies were a single entity - and therefore cannot shed light on the separate financial status of subsidiaries. Nonetheless, White's review of 22 randomly selected companies that engage in risky activity shows no significant trend toward increasing the number of subsidiaries. See White, supra note 10 , at 1388 . At the same time, there are perfectly legitimate reasons, such as tax and foreign licensing requirements, for conducting business through subsidiaries. Even if a large corporation conducts a portion of its business in a foreign jurisdiction and does not wish to expose all of its assets to liability in that jurisdiction, that is different from judgment proofing so long as the subsidiary is adequately capitalized. See id. at 1390 . White also provides examples where prominent companies paid their subsidiaries' liabilities. See id. at 1391-93 (discussing Union Carbide's response to the Bhopal disaster, the Exxon Valdez oil spill, and Dow Corning's breast implant litigation).

46. For example, White argues that the only companies that should raise concerns over judgment proofing are those that might "perpetrate mass torts and be subject to large statutory liability." White, supra note 10 , at 1396 . However, "[t]o commit large torts, one must do large business, and to do large business normally requires substantial assets." Id. This argument may be flawed, however, because a company with leased assets can commit the same torts, and thereby become subject to the same liability, as one that owns the assets. See also id. at 1399-1412 (advancing other arguments as to why businesses would be expected to maintain substantial assets or insurance in lieu of assets).

47. See Franco Modigliani \& Merton H. Miller, The Cost of Capital, Corporation Finance and the Theory of Investment, AM. ECON. REV., June 1958, at 261, 268.

48. See White, supra note 10 , at 1394 (noting that this must be done while creditors are not paying attention).

49. See id. White argues, nonetheless, that involuntary creditors may be indirectly protected by contractual creditors who "appreciate the risk ... when firms make themselves judgment proof and ... demand corresponding compensation." Id. at 1396. However, a company could compensate voluntary creditors without compensating involuntary creditors. Providing compensation only to contractual creditors also would undercut White's subsequent argument that "conditions that the prospective contract creditors will demand before lending to a judgment proof company may prove to be so costly that the debtor will choose to capitalize the company more fully to avoid those [conditions]." Id. at 1397. White indeed acknowledges that "the interests of the contract creditors and the [involuntary] creditors are not exactly aligned. Indeed, the contract creditors might take security and thus protect themselves to the detriment of later [involuntary] claimants." Id. at 1398. But he 
I next show that judgment proofing is unlikely to become endemic, as predicted by LoPucki; but the reasons it will not spread are different than those advanced by White.

\section{ANALYSIS}

LoPucki's central assertion is that the advent of securitization and other innovative business transactions is causing the death of liability. However, by focusing on the structuring of business transactions, 50 he ignores the important differences between arm's length and non-arm's length transactions. ${ }^{51}$ Different motivations, perspectives, and costs are inherent in each. In an arm's length judgment proofing transaction, each company will seek independent gain, whereas in a non-arm's length structure, judgment proofing only needs to benefit the controlling company. My analysis therefore addresses arm's length and non-arm's length transactions separately.

\section{A. The Structuring of Arm's Length Business Transactions Should Not Give Rise to Judgment Proofing}

I first test this proposition in the context of each of the potentially arm's length structures referenced by LoPucki, including sale-leaseback, securitization, and his "essential structure." 52 I then examine the proposition in light of the possibility that arm's length parties could attempt to take advantage of the value that judgment proofing would wrest from future involuntary creditors.

To provide a context for the analysis, consider companies $F 1$ and $F 2$, which are unrelated. $F I$ is about to sell its assets to $F 2$ and lease them

argues that we do not observe this because the contractual "creditor may fear that the assets [taken as security] - even with a value equal to the amount of the debt while the concern is operatingwill be inadequate to satisfy their claims on default." Id. White illustrates his argument by an example in which inventory purchased for $\$ 100$ million may turn out to be worth only $\$ 10$ or $\$ 20$ million on the default of the business if the inventory has to be scrapped or sold at low prices to others. See id. at 1399. That argument, however, fails to recognize the customary secured lending practice of providing collateral with a value sufficiently in excess of the claim and not, as White suggests, merely equal to the claim. This practice helps to ensure payment in full even if the firm stops operating.

50. Professor White also appears to focus solely on transaction structure. For example, he notes early in his article that "distributing one's assets to shareholders in preference to creditors [has] been practiced for hundreds of years; [it is] explicitly not the subject of Professor LoPucki's complaint." White, supra note 10, at 1364. Nonetheless, White later acknowledges that "to judgment proof [a debtor] requires a second step, namely the disposition of the net proceeds [of the judgment proofing transfer] by dividends to shareholders." Id. at 1375 n. 49.

51. See note 34 supra and accompanying text (observing that although LoPucki rarely distinguishes whether he is focusing on arm's length or non-arm's length transactions, his analysis is intended to include both).

52. See notes 29-31 supra and accompanying text. 
back-a sale-leaseback being the threshold transaction in which $F 1$ converts its ordinary assets into securitizable income-producing assets (in the form of leases) ${ }^{53}$ while still being able to use the original assets. $F 1$, however, would have an immediate and significant disincentive against engaging in this threshold transaction: It would be taxed on the sale income.54

If $F 1$ nonetheless engages in the sale-leaseback, the lease theoretically can be securitized.55 Securitization has been alleged to be the most dangerous threat to liability.56 But a close analysis shows that allegation to be unfounded. Formalistically, only the buyer of the original assets, $F 2$, can lease those assets back to $F 1$, and therefore only $F 2$ will hold leases which can be securitized.57 Thus, $F 1$, the very company that is in danger of becoming judgment-proofed by securitization, would not technically be a party to the securitization transaction. 58 More substantively, securitization is merely a way of allowing $F 2$ to finance the purchase of $F 1$ 's assets, with $F 1$ receiving the sale proceeds. Judgment proofing only could result from $F 1$ 's disposition of those sale proceeds for less than their value. That disposition, if it occurred, would be independent of the securitization transaction.

Even an argument that securitization indirectly facilitates judgment proofing by enabling $F 2$ to finance the purchase of $F 1$ 's assets would fail because $F 2$ could finance the purchase of those assets through traditional

53. To the extent $F 1$ already owns income-producing assets, it could securitize those assets without engaging in a sale-leaseback. However, income-producing assets are only a fraction of the value of a typical company's assets. See, e.g., MiCHAEL A. DIAMOND, ERIC G. FLAMHOLTZ \& DiANA TROICK FLAMHOLTZ, FINANCIAL ACCOUNTING 762 (2d ed. 1990) (citing the 1988 balance sheet of Toys 'R Us, Inc., in which the ratio of income-producing assets to total assets was $5.3 \%$, as an illustrative financial statement); CHARLES T. HORNGREN, GARY L. SUNDEM \& JOHN A. ELLIOT, INTRODUCTION TO FINANCIAL ACCOUNTING 763 (5th ed. 1993) (using the 1991 balance sheet of Wal-Mart Stores, Inc., in which the ratio of income-producing assets to total assets was $7.5 \%$, as a model throughout the book). Moreover, I later show that only $F 2$, not $F 1$, could securitize the income-producing lease assets created by the sale-leaseback. See notes 57-58 infra and accompanying text.

54. Fl's gain will be taxed as either capital gain or ordinary income, or a combination, depending on the nature of the assets sold. For corporate sellers, however, the rate on both types of gain is $35 \%$, although the characterization as gain or ordinary income will govern $F 1$ 's ability to offset the gain with capital, versus ordinary, losses. See I.R.C. $\$ \S 1221,1231,1245,1250(1986 \&$ Supp. 1999). Thus, if $F 1$ sells $\$ 10$ million of assets to $F 2$, and $F 1$ 's gain on sale is high because the assets had appreciated while being held by $F 1$ or constitute depreciable property with respect to which depreciation deductions have been taken, $F 1$ may have to pay up to $\$ 3.5$ million in federal taxes. FI's gain also may be subject to taxation under state law.

55. Although I follow LoPucki in focusing on the sale-leaseback model, my analysis applies to any other model, such as a sale and license-back, that transfers ownership of $F I$ 's assets to $F 2$ while allowing $F l$ to continue to use those assets.

56. Recall that securitization has been called the "silver bullet capable of killing liability." Death of Liability, supra note 1, at 30.

57 . F2 could be either an SPV or an operating company; the only requirement in this discussion of arm's length judgment proofing is that it is unrelated to $F 1$.

58. $F 2$ would be the originator of the income-producing assets as well as the issuer of securities to capital market investors; $F 1$ merely would be the obligor on those assets. 
techniques, such as bank borrowing. ${ }^{99}$ The possibility that securitization or other financing techniques might be misused should not undermine their overall legitimacy. 60 In any event, the likelihood that $F 2$ would be able to obtain securitization or other financing on the strength of a lease to $F 1$ is extremely remote. Few investors or bank lenders would be willing to take the risk that future rentals of a judgment proof lessee would be paid.61

The alarming description of Exxon's ability to judgment proof itself through securitization vividly demonstrates my point. Recall the claim that

[b]y selling any asset to a bankruptcy-remote entity and leasing it back, the debtor can transform it into an "income-producing" asset that can then be securitized.

... To grasp the enormous potential, assume that, through a series of asset securitizations, Exxon Corporation disposes of all of its assets. . . Because Exxon contracts to continue use of each asset even as Exxon sells it, the operations of Zero-Asset Exxon remain exactly as they were when it was a multibillion dollar company. 62

Exxon first sells its assets to the bankruptcy-remote entity and receives a cash purchase price, ${ }^{63}$ and the entity then leases those assets back to Exxon, with the lease becoming the income-producing asset. But the bankruptcyremote entity alone owns that income-producing asset. Exxon merely is a lessee. Therefore, on a formalistic level, only the entity, and not Exxon, could sell that asset in a securitization transaction.

More substantively, Exxon's creditors would not have to worry about a securitization transaction. In the unlikely event that the bankruptcy-remote

59. For example, $F 2$ could borrow money secured by a pledge of the lease and its underlying assets. $F 1$ also could judgment-proof itself absent a sale-leaseback by transferring its assets as dividends to its shareholders. A company may dividend any assets, whether or not in the form of cash, to its shareholders. JAMES D. COX, THOMAS LEE HAZEN \& F. HODGE O'NEAL, CORPORATIONS $\S 20.1$, at 20.3 (1995). However, $F 1$ would not be able to continue to use the assets absent a sale-leaseback.

60. Securitization has valid business reasons, such as reducing the cost of capital. Reducing the cost of capital "'results in enhanced output, and consumers as a whole are better off." Peter Coy, Doing Business, Bus. WK., Aug. 31, 1998, at 98 (quoting Nobel Prize winner Myron S. Scholes).

61. See notes 95-97 infra and accompanying text (explaining why investors will not want to take the risk of a judgment proof lessee). Investors almost certainly will become aware of the risk because if $F 2$ fails to disclose $F I$ 's intention to judgment-proof itself, $F 2$ may be liable for securities fraud. Also, while it is not inconceivable that a judgment proof $F 1$ sometimes may hope to generate sufficient business profits from its use of the leased assets to be able to pay its future lease rental obligations, $F 1$ still may be forced into bankruptcy during the lease term if significant other liabilities arise, such as tort judgments. Ironically, then, there is an inverse-not a direct-relationship between securitization and judgment proofing of $F I$. The stronger $F I$ 's financial health, the more likely a securitization would succeed; the weaker its financial health (a judgment proof $F I$ being very weak), the less likely a securitization would succeed.

62. Death of Liability, supra note 1, at 25-26 (footnotes omitted).

63. Exxon therefore now owns the cash instead of hard assets. 
entity is able to finance the purchase of Exxon's assets, ${ }^{64}$ the funds raised would be paid to Exxon as the purchase price. Hence, Exxon's hard assets are merely replaced by cash.65 Because Exxon's creditors are only interested in repayment of their claims, they should be satisfied with the cash. Only a subsequent disposition of that cash, unrelated to the securitization, would cause judgment proofing. Securitization itself is not a judgment proofing technique.

Next consider the parent-subsidiary ownership strategy. (This strategy is not technically arm's length; 66 however, I include it in this discussion because it is one of the transactional structures referenced by LoPucki.) Although the strategy "is in wide use among the largest companies in America,"67 there is no evidence that it causes judgment proofing. However, there is significant evidence that parent-subsidiary ownership allows a manufacturing company to obtain lower-cost financing, thereby arguably benefitting its involuntary creditors by lowering the company's overall debt burden. 68

64. Potential investors would question whether Zero-Asset Exxon would pay its rentals. See notes 95-97 infra and accompanying text (explaining the improbability that $F 2$ would be able to obtain financing on the strength of a lease to a judgment proof lessee).

65. However, if the bankruptcy-remote entity is unrelated to Exxon, the sale-leaseback would reduce Exxon's value due to taxes. See note 54 supra and accompanying text (discussing tax treatment of an arm's length sale-leaseback transaction). But if the bankruptcy-remote entity is related to Exxon and part of its consolidated tax group, Exxon may be able to defer paying taxes on the sale. See note 145 infra and accompanying text (discussing tax treatment of a non-arm's length sale-leaseback transaction).

66. See notes 139-142 infra and accompanying text (analyzing a generic parent-subsidiary ownership strategy as an example of a non-arm's length judgment proofing transaction).

67. Death of Liability, supra note 1 , at 21 . Indeed, this strategy has long been used by such prominent companies as Ford (and its finance subsidiary, Ford Credit Corporation), Chrysler (and its finance subsidiary, Chrysler Credit Corporation), General Motors (and its finance subsidiary, General Motors Acceptance Corporation (GMAC)), BMW (and its finance subsidiary, BMW Finance Company), and Allis Chalmers (and its finance subsidiary, Allis Chalmers Credit Corporation).

68. The parent-subsidiary strategy permits the manufacturing company to obtain lower-cost financing in the following, indirect, manner: Its subsidiary, not burdened with the business risks of an operating company, is able to obtain low-cost institutional or capital market financing. See, e.g., John F. Connolly, Finance Subsidiaries: Establishment, Utilization, and Constraints, 414 PLI/ COMM 297, 301 (1987) ("Securities issuances by a finance subsidiary generally receive higher ratings (frequently triple $A$ ) by the rating agencies, thereby enabling a finance subsidiary to issue securities at lower interest rates ... than a securities issuance by its parent association."). The subsidiary then uses the proceeds of that financing to stimulate sales of its parent's products by providing consumers with low-cost credit. For example, a consumer may chose to purchase a BMW automobile because BMW Finance Company, which can borrow more cheaply than could BMW, is able to finance the consumer at a low interest rate. Professor White notes that the parent-subsidiary strategy also is useful for incorporating subsidiaries under foreign law for regulatory or tax reasons, to limit exposure of a large company's U.S. assets in a foreign jurisdiction where the subsidiary is already adequately capitalized, or for "managerial and organizational efficiencies in operating a particular business as a separately incorporated subsidiary." White, supra note 10, at 1390-91. Furthermore, some securitization transactions utilize a parent-subsidiary strategy as part of a "twotier structure." See Peter V. Pantaleo, Herbert S. Edelman, Frederick L. Feldkamp, Jason Kravitt, Walter McNeill, Thomas E. Plank, Kenneth P. Morrison, Steven L. Schwarcz, Paul Shupack, and 
LoPucki apparently draws an incorrect conclusion from the parent-subsidiary ownership strategy because he assumes, without basis, that Operations (the parent) "distributes any proceeds beyond its immediate cash needs to its shareholders." 69 Not only does that assumption not reflect business reality,70 it illustrates the failure to distinguish between structuring an arm's length transaction and the completely unrelated step of paying dividends. ${ }^{71}$

Finally, examine LoPucki's "essential structure" of judgment proofing.72 If a company wishes to judgment proof itself, it would have to transfer its assets.73 It is possible to divide potential recipients of the transfer into three categories: the company's creditors, the company's owners (its shareholders), and third parties other than creditors and owners. A transfer of assets to creditors would be the antithesis of judgment proofing. A transfer of assets to shareholders could cause judgment proofing, but the payment of such dividends is not necessarily dependent on the essential structure. A transfer of assets to unrelated third parties should not cause judgment proofing because no rational company will give away its assets without demanding equivalent value in return. Thus, in an arm's length context, none of these transfers causes judgment proofing.

The failure to recognize that structuring an arm's length transaction does not cause judgment proofing stems from a failure to trace cash flows. This is exemplified by Professor LoPucki's use of the Rockefeller Center financing to illustrate the use of judgment proofing techniques:

The land and buildings constituting Rockefeller Center were owned by two partnerships, referred to collectively as Rockefeller Center Properties (RCP).

Barry Zaretsky, Rethinking the Role of Recourse in the Sale of Financial Assets, 52 Bus. LAW. 159, $162 \mathrm{n.8}$ (1996) (describing the two-tier structure). Nevertheless, the parent benefits directly because it receives the proceeds of the transaction.

69. Death of Liability, supra note 1 , at 20.

70. It simply is unrealistic to assume that the primary purpose of raising capital is to distribute it to shareholders. Companies generally raise capital to continue or to expand their businesses. See, e.g., note 68 supra (explaining how the parent-subsidiary strategy would help BMW sell its cars).

71. Without the dividend payment, the parent-subsidiary strategy would not, in and of itself, cause judgment proofing because the parent retains the equity interest in the subsidiary and, in any event, only needs to transfer to the finance subsidiary sufficient assets to support the financing. An extraordinary transfer that renders the parent insolvent could be avoided as a fraudulent conveyance. See notes 162-175 infra and accompanying text (discussing the application of fraudulent conveyance law to judgment proofing and showing that existing law restricts the use of non-arm's length transactions, including the parent-subsidiary structure, for judgment proofing).

72. The "essential structure" comprises a "symbiotic relationship between two or more entities, in which one of the entities generates disproportionately high risks of liability and another owns a disproportionately high level of assets." Essential Structure, supra note 2, at 149).

73. No transfer would be needed, however, where the liability-generating company is undercapitalized ab initio. The company then would need to lease its assets from third parties. But in an arm's length context, rational lessors are unlikely (without additional protection, such as shareholder guaranties) to agree to lease assets to a judgment proof company. See note 61 supra and accompanying text (explaining that a judgment proof lessee might not pay its future rentals). 
Nov. 1999]

The partners were two private corporations ... that were in turn owned by unnamed members of the Rockefeller family and Mitsubishi Estate Company, Inc. Rockefeller Center was appraised at $\$ 1.25$ billion in 1994. The ownership structure was hard judgment proofed by a mortgage in the amount of approximately $\$ 1.3$ billion [on the Rockefeller Center land and buildings,] in favor of Rockefeller Center Properties, Inc. (RCPI), a public corporation that apparently was created to and did deal at arm's length with RCP. ${ }^{74}$

However, the conclusion that the mortgage in favor of RCPI "hard judgment proofed" the transaction ignores that RCP receives the mortgage loan proceeds. ${ }^{75}$ After the mortgage loan was made, RCP had $\$ 1.3$ billion of new assets (in the form of proceeds) and $\$ 1.3$ billion of new debt, ${ }^{76}$ preserving the net worth that RCP enjoyed prior to the loan77-hardly judgment proofing!

Accordingly, none of the proffered examples stands for the proposition claimed: that innovative business transactions give rise to judgment proofing. I next show that it is unlikely, even in theory, that arm's length business transactions can be used for judgment proofing.

\section{B. Arm's Length Business Transactions Are Unlikely to Take Advantage of the Value That Judgment Proofing Would Wrest From Future Involun- tary Creditors}

There remains a conceptual risk of judgment proofing in arm's length business transactions. A company, FI, may wish to increase its shareholder value by taking value from potential future involuntary creditors. Let $\Delta$ stand for the amount of value that judgment proofing is expected to take from such creditors..$^{78} F 1$ could attempt to contract with one or more unrelated companies to share the value of $\Delta$ if the unrelated companies-which I

74. Id. at 1423 (citing ROCKEFELLER CTR. PROPERTIES, INC., FORM 10-K FOR THE YEAR ENDING DECEMBER 31, 1995, at 6 (1996) [hereinafter RCPI FORM 10-K]).

75. RCP owned Rockefeller Center free and clear before it took out the mortgage loan. See RCPI FORM 10-K, supra note 74, at 3, 32, 76. From RCP's standpoint, the loan provided funds by which to reorganize by paying outstanding creditor claims. Id. at 76. For RCPI, the loan was an investment. It was convertible at RCPI's option into a $71.5 \%$ equity interest in Rockefeller Center. Id. at 32. Furthermore, RCP's Chapter 11 plan provided that, upon confirmation, Rockefeller Center would be transferred to RCPI in satisfaction of the loan and mortgage. Id. at 62,64 .

76. See id. at 5 (describing the amount of the mortgage loan as $\$ 1.3$ billion).

77. The assertion that "[h]ad portions of Rockefeller Center toppled into the streets of New York and caused billions of dollars in damages while this structure was in place, the judgment creditors probably could not have reached either the value of Rockefeller Center or the wealth of the Rockefeller family and the Mitsubishi Estate" is inaccurate. Virtual Judgment Proofing, supra note 2 , at 1424. The creditors could have reached the same value of RCP's unencumbered assets, $\$ 1.25$ billion, that would be available absent the mortgage loan. Admittedly, some portion of the equity might be lost in foreclosure; but if that is the problem, the more appropriate solution is to reform the collateral foreclosure process.

78. In computing $\Delta, F 1$ 's potential liability to future creditors therefore should be discounted by the probability that liability will not arise. 
collectively refer to as $F 2$-help $F 1$ to become judgment proof. Let $\kappa$ stand for the amount of compensation that $F 2$ would require to participate in judgment proofing. If $\kappa$ is less than $\Delta$, judgment proofing may occur.

$F 1$ could attempt to judgment proof itself by bifurcating ownership and use of its assets. If $F 1$ has existing assets, it would try to sell those assets to, and lease them back from, $F 2$, and then dispose of the sale proceeds by paying dividends to its shareholders. ${ }^{79}$ If $F 1$ is undercapitalized ab initio, it already would be judgment proof and therefore simply would try to lease its operating assets from $F 2$. In either case, $F 2$ would demand compensation in excess of ordinary market-rate lease rentals because $F 1$, being judgment proof, may go bankrupt during the lease term, creating a risk that the rentals will remain unpaid.

There are only three broad forms of compensation that $F 1$ could offer $F 2$. One is lease rentals that exceed market-rate rentals; another is a share in $F 1$ 's equity; the third is a lump-sum payment. Whichever form (or combination of forms) is chosen, it would represent FI's offer to share a portion of $\Delta$ with $F 2$ in exchange for the judgment proofing. ${ }^{80}$ I next show that the likelihood that $F 1$ and $F 2$ will be able to agree on compensation is, at best, remote because the value of judgment proofing to $F 1$ may well be less than the costs it would impose on $F 2$.

My analysis starts by showing that the only realistic form of compensation is a lump-sum payment. Consider the alternatives: If $F 1$ offers abovemarket lease rentals, $F 2$ would rationally agree to this deal only if it is comfortable that the present value of the rentals paid will at least equal $\mathrm{\kappa}$. But $F 2$ will have difficulty reaching that conclusion. FI's ability to pay rentals will

79. Recall that the essential judgment proofing step is really the asset disposition for less than equivalent value, in this case the dividend. I later show that such dispositions are restricted by fraudulent conveyance law, see notes 162-175 infra and accompanying text, and, in the case of dividends, also by corporation law, see notes 200-206 infra and accompanying text. LoPucki nonetheless argues that if $F 1$ does not distribute the sale proceeds to its shareholders, it "will invest them in the business, in which case the size of the business, and presumably its capacity to generate liability, will be increased," an effect he calls "a kind of soft judgment proofing, because the company's ratio of assets to potential liabilities has been reduced." Virtual Judgment Proofing, supra note 2 , at 1430 . His argument is not convincing, however, because so long as assets exceed potential liabilities, creditors will be paid in full; and freezing a company's level of risk would undermine its ability to enter into new, and therefore potentially risky, ventures. See Steven L. Schwarcz, Rethinking A Corporation's Obligations to Creditors, 17 CARDOZO L. REV. 647, 680-82 (1996) (arguing that, absent covenants or insolvency, creditors have no right to preserve their debtor's economic position). Furthermore, if $F 1$ wants to reduce its ratio of assets to liabilities, it more easily could do so by borrowing on a secured basis and using the loan proceeds to expand the business. In that context, I have shown that rather than creating a soft judgment proofing that harms unsecured creditors, new money secured borrowing actually increases the expected value of their claims. See Easy Case, supra note 15.

80. $F 1$ could not assign to $F 2$ an actual share in $\Delta$ because $\Delta$ represents a cost saving, not a revenue. See note 91 infra and accompanying text. 
depend entirely on its success in generating profits with the leased assets, 81 a business risk that $F 2$ may not wish to take.82 Furthermore, because $F 1$ is judgment proof, it might go bankrupt during the lease term, 83 creating legal uncertainty whether $F 2$ will be paid its rentals. ${ }^{84}$ Although theoretically some amount of rentals might be high enough to offset these risks, F1 would not agree to pay rentals that are so high as to deprive it of $\Delta .{ }^{85}$ Above-market rentals are therefore a dubious incentive. 86

If $F 1$ offers a share in its equity, $F 2$ again would rationally agree to this deal only if $F 2$ is comfortable that the present value of that equity interest will at least equal $\mathrm{K}$. But $F 1$ 's lack of assets and its risk of bankruptcy mar-

81. $F 2$ cannot even require $F 1$ to collateralize its lease obligations because $F 1$, being judgment proof, has no significant assets. However, where one or more of $F I$ 's shareholders owns a significant equity interest, such as in a closely held corporation, that shareholder might offer to guaranty Fl's lease obligations in exchange for the judgment proofing. Whether such a shareholder will exist and, if so, whether $F 2$ will find its guaranty satisfactory as a credit matter are questions of fact. I later argue that shareholders may be reluctant to offer such guaranties because, by doing so, they risk substantive consolidation if $F l$ later goes bankrupt. See notes 182-196 infra and accompanying text (discussing substantive consolidation).

82. Cf. Easy Case, supra note 15, at $455-56$ n.131 (explaining that "[l]enders ... do not make loans to debtors unless they believe the debtors are viable business entities"). The same type of credit analysis that is applicable to lending is also applicable to leasing. See Electronic mail from John D. Forsyth, Professor of Finance, Fuqua School of Business, Duke University, to Thomas R. Loeser, author's research assistant (Sept. 29, 1998) (on file with author); J. FRED WESTON \& THOMAS E. COPELAND, MANAGERIAL FINANCE 1000-04 (9th ed. 1992) (applying the same credit analysis to leasing and lending credit decisions).

83. Fl might go bankrupt because it would be unable to pay any significant debts that might accrue, and thus creditors on those debts could force $F I$ into involuntary bankruptcy on the basis that it "is generally not paying [its] debts as such debts become due unless such debts are the subject of a bona fide dispute." 11 U.S.C. $\$ 303(\mathrm{~h})(1)$ (1988) (setting forth involuntary bankruptcy standards). I later discuss that judgment proofing and the consequent risk of bankruptcy impose costs on $F 1$ itself, which $F 1$ would have to subtract from $\Delta$. See notes 120-123 infra and accompanying text.

84. Bankruptcy automatically stays $F 1$ 's obligation to pay those rentals even if it has the income to do so. See 11 U.S.C. $\$ 362$ (1988 \& Supp. 1999). If F1 continues to use the leased assets, it only has to pay $F 2$ for their reasonable use value, an amount which is likely to be significantly less than above-market lease rentals. See, e.g., In re ICS Cybernetics, Inc., 111 B.R. 32, 40-41 (Bankr. N.D.N.Y. 1989). Ultimately, FI must either assume (affirm) or reject (terminate) the lease. See 11 U.S.C. $\$ 365$ (1988). If $F 1$ rejects the lease, $F 2$ receives the assets back but takes the risk that the value of the retumed assets (their "residual value") might be low. (F2 also would have a pre-petition unsecured claim for breach, but its recovery on that claim likewise may be low.) If $F 2$ assumes the lease, FI will be paid its rentals. See 11 U.S.C. $\S 365(b)$ (1988 \& Supp. 1999); DAVID G. EPSTEIN, STEVE H. NICKLES \& JAMES J. WHITE, BANKRUPTCY \$ 5-5 (1993). However, $F I$ will assume a lease only where the rentals payable for the leased assets are less than the market cost of renting equivalent assets. That is, of course, unlikely where the rentals under the original lease are above market.

85. Cf. notes 117-118 infra and accompanying text (analyzing the relationship between the amount that $F 2$ would demand as compensation and the amount that $F 1$ would be willing to pay).

86. $F 2$ also faces a risk that a bankruptcy court might hold that the underlying sale-leaseback transaction does not even create a lease. See, e.g., In re PCH Assocs., 804 F.2d 193, 200 (2d Cir. 1986) (holding that the "economic substance" of the sale-leaseback transaction in question did not create a true lease for purposes of 11 U.S.C. $\$ 365(d)(3),(4))$. 
ginalize the value of its equity, which may turn out to be worth nothing. Moreover, by taking ownership of $F 1$ 's equity, $F 2$ might make itself liable for $\Delta .87$ Thus, offering $F 2$ a share in $F 1$ 's equity likewise does not appear to be a sufficient incentive to encourage arm's length judgment proofing.

However, the third possible form of compensation-offering F2 a lumpsum payment-might appear to be a viable strategy for judgment proofing. $F 2$ could require payment as a condition to judgment proofing: Payment would be made directly or, if $F l$ does not have the money on hand, by adjusting the purchase price in the sale-leaseback. 88

At least where future involuntary claims are expected to be very large, such as for companies that are subject to mass tort liability, it might seem that there will be many cases where $\kappa$ will be less than $\Delta$ because an arm's length judgment proofing contract will be entered into where $\mathrm{K}$ is less than $\Delta$. But a close analysis of $\Delta$ shows, to the contrary, that $\kappa$ may well exceed $\Delta$ even in mass tort cases. $\Delta$ represents the amount of value that judgment proofing takes from $F 1$ 's future involuntary creditors. ${ }^{89}$ That amount is not the amount of future involuntary creditor claims, which can be considerable. Rather, $\Delta$ is limited to the value of $F 1$ 's interest in the assets used in its business. 90 That is because, absent judgment proofing, $F l$ 's creditors could claim only against those assets. ${ }^{91}$

$F 1$ and $F 2$ therefore will be able to reach a deal only if the amount of compensation that $F 2$ would require, $\kappa$, is less than the value of $F 1$ 's assets. ${ }^{22}$ I next show, however, that even if $F 1$ is a company with significant assets, $\kappa$ may well exceed their value. Although this first appears counterintuitive, it follows from the recognition that $\kappa$ must at least offset the sizable costs that

87. See notes $183,186 \& 197-199$ infra and accompanying text (discussing the risk that $F 2$ as shareholder might become directly liable for $\Delta$ under theories of substantive consolidation and piercing the corporate veil).

88. In the second case, if $F 1$ sells $\$ 1,000,000$ of assets to $F 2$ and leases them back, and the lump-sum compensation is $\$ 250,000$, then $F 2$ would only pay $\$ 750,000$ as a purchase price for the assets.

89. See note 78 supra and accompanying text.

90. Thus, if $F I$ owns an asset outright, the value of its interest in that asset will be equal to the value of the asset. But if $F 1$ merely leases an asset, the value of its interest in that asset will depend on whether Fl's lease cost is above or below the cost of leasing a similar asset.

91. From $F 1$ 's perspective, $\Delta$ is not a revenue but merely a potential cost saving, resulting from avoiding creditor claims. Because the most $F 1$ could save by avoiding claims is the value of its assets, $\Delta$ is necessarily limited to that value even if the amount of future involuntary creditor claims is greater. Cf. S. Shavell, The Judgment Proof Problem, 6 INT'L REV. L. \& ECON. 45, 45 (1986) ("An injurer will treat liability that exceeds his assets as imposing an effective financial penalty only equal to his assets; an injurer with assets of $\$ 30000$, for example, will treat an accident resulting in liability of $\$ 100000$ identically with an accident resulting in liability of only $\$ 30$ 000.").

92. I later refine this argument by showing that $F 1$ and $F 2$ will be able to reach a deal only if $\kappa$ is significantly less than the value of F1's assets. See note 138 infra and accompanying text. 
judgment proofing would impose on $F 2$. These costs potentially include a financing premium, increased liability risks, and reputation and agency costs.

A financing premium would apply whenever $F 2$ finances the purchase of the assets to be leased to $F 1.93$ Because companies rarely have significant amounts of cash on hand, $F 2$ is very likely to have to finance the purchase of those assets. Unless $F 2$ is a highly creditworthy company, in which case the other costs discussed below will be greater, 94 the financier customarily would require the financing to be secured by an assignment of the lease. 95 However, if $F I$ is judgment proof, its ability to make lease payments is uncertain, rendering the assignment of the lease almost valueless. $F 2$ then may be unable to obtain financing, in which case the judgment proofing attempt would fail ab initio. ${ }^{96}$ Even if $F 2$ could obtain financing, it would have to pay the financier a significant premium to overcome the credit risk of a judgment proof lessee. ${ }^{97}$

Other costs, however, apply whether or not $F 2$ finances its purchase of the assets to be leased to $F 1$. I later show that if $F 2$ helps judgment proof $F 1$, it may become liable to FI's creditors under existing law.98 Those creditors

93. Recall that $F 2$ helps judgment proof $F 1$ by buying its assets and leasing them back. See note 79 supra and accompanying text.

94. See notes $114 \& 116$ infra and accompanying text (arguing that the more creditworthy F2 is, the greater its reputation and agency costs will be).

95. "Lenders generally will not make loans, secured or otherwise, unless they have 'two ways out, meaning two potential methods of repayment. One way out may well be the collateral's liquidation value [which, in the case referred to above, would come from a pledge of the assets purchased] but the second way out is usually cash flow [which, in the case referred to above, would come from an assignment of the lease]." Easy Case, supra note 15, at 455 n.131. Where the market value of the assets could fluctuate, a pledge of the assets alone almost certainly would be insufficient.

96. In another context, Professor LoPucki implicitly acknowledges the financier's expected refusal to advance funds. When discussing whether a company's right to do business could be conditioned on demonstrating financial responsibility as evidenced by the posting of a surety bond, he argues that no insurer would issue a bond unless the company has sufficient assets to reimburse the insurer if the bond is ever paid. See Death of Liability, supra note 1 , at 88.

97. In theory, at least, $F 1$ could self-finance $F 2$ 's purchase by taking back a note from $F 2$ for the purchase price, thereby eliminating $F 2$ 's need to obtain financing. $F 1$ then could transfer that note, or interests therein, as a dividend to its shareholders. However, in an arm's length transaction, self-financing is unlikely. Fl ordinarily would want cash for the sale of its assets, and would not want to take $F 2$ 's credit risk. A note or other promise to pay offered by $F 2$ would introduce risk into the valuation of the sale price which would necessarily decrease the amount realized by $F 1$. See WESTON ET AL., supra note 82 , at 802 ("Ultimately the seller firm bears the risk of nonpayment when credit is extended.").

98. See notes 179-188 infra and accompanying text (analyzing the theories under which $F 2$ may become liable to $F 1$ 's creditors). If $F 2$ were a foreign entity without U.S. contacts, it might be able to avoid some of this liability, depending on the law of its home jurisdiction. But $F 2$ may subject itself to jurisdiction and liability anyway if it ever needs to enforce the lease in the U.S. Moreover, a foreign $F 2$ might face such costs as bad publicity (which could prevent $F 2$ 's future entry into U.S. markets), additional taxation under its home jurisdiction's laws, and inability to finance the purchase of $F 1$ 's assets because foreign capital sources tend to be smaller than those in 
are likely to want to impose liability because a judgment proof $F 1$ will be unable to pay its creditors, leaving $F 2$ as the only realistic "deep pocket" defendant.99 Therefore, the more creditworthy $F 2$ is, the more likely it will be named as a defendant. 100

The future claims of $F 1$ 's creditors against $F 2$ will be difficult to predict ex ante, ${ }^{101}$ and creditors also might be able to recover punitive and treble damages. ${ }^{102}$ Those claims therefore could exceed $\kappa$. It appears highly unlikely that $F 2$ would take a business risk that could subject it to another company's liabilities in an amount greater than the compensation received for taking the risk. Moreover, those claims may even exceed $\Delta-$ which, recall, is limited to the value of $F 1$ 's interest in its assets even if the amount of future involuntary creditor claims is greater ${ }^{103}$-because $F 1$ 's creditors could assert their entire claims against F2.104 Ironically, therefore, the higher F1's exposure to a large and unpredictable risk (such as mass tort claims), the greater the deterrent to judgment proofing, because $F 1$ 's liability would be limited to $\Delta$ whereas $F 2$ 's liability might not be so limited.105

Even where $F 2$ is able to assert technical defenses against liability, such as defenses based on its separate corporate identity, there is an inherent litigation risk in any lawsuit, particularly where the defendant appears to be en-

the U.S. $F 1$ itself might be unwilling to sell its assets to a foreign $F 2$ if, under the laws of $F 2$ 's home jurisdiction, $F l$ has less assurance that it will be able to continue to use those assets.

99. Unless $F I$ 's shareholders were involved in the judgment proofing, lawsuits against them for return of dividend payments are unlikely to be successful because of limited shareholder liability. Furthermore, if $F 1$ has numerous shareholders, they might be difficult to locate and the amount of the claim against each might not be worth the cost of litigating that claim.

100. See, e.g., John Leo, It's a Tort World After All, U.S. NEWS \& WORLD REP., Aug. 17, 1998, at 6 (referring to tort litigation arising from a fire at the Dupont Plaza Hotel in Puerto Rico: "Following the time-honored deep pockets strategy, lawyers for victims did not sue the perpetrators [who were unhappy union members employed by the hotel]. They sued hundreds of companies that made various hotel items that burned on the scene."). Thus, a low likelihood that $F 2$ will have to pay the financing premium referred to in the prior paragraph is offset by a high likelihood that $F 2$ will bear the costs referred to in this paragraph.

101. By ex ante, I mean at the time that judgment proofing occurs, as opposed to a later time when future involuntary claims arise. Contracts are made based on ex ante, not ex post, expectations. For example, "if a contract calls for the delivery of wheat on a fixed date at $\$ 3$ a bushel, the fact that on that date the market price is $\$ 6$ will not operate to discharge the contract." RICHARD $A$. POSNER, ECONOMIC ANALYSIS OF LAW $\$ 4.4$, at 115 (5th ed. 1998).

102. See notes 209 \& 228 infra and accompanying text (explaining that $F 1$ 's creditors may be able to claim punitive damages against $F 2$ on a tort theory and treble damages under RICO).

103. See note 91 supra and accompanying text.

104. See text accompanying notes 162-255 infra (describing the theories under which Fl's creditors could assert their entire claims against F2). In K.M.C. Co. v. Irving Trust Co., for example, the defendant, based on a refusal to lend $\$ 800,000$, was held liable for the plaintiff's damages of \$7.5 million. 757 F.2d 752, 754-55 (6th Cir. 1985).

105. F2's liability would not be so limited where the value of its assets exceeds $\Delta$. Thus, any argument that a company could have such inherently high risks that its judgment proofing benefits exceed its costs would be fallacious. 
gaging in morally culpable action. ${ }^{106}$ If $F 2$ ultimately is likely to win the litigation, $F 2$ still may prefer to settle than to take the litigation risk, and settlement costs can be significant.107 $F 2$ therefore will require additional compensation, such as a risk premium, that offsets these risks. ${ }^{108}$

F2 also may require compensation for potential reputation and agency costs. ${ }^{109}$ The former is caused by the bad publicity arising out of judgment proofing and includes the following risks: that F2's debt rating may be lowered by rating agencies, impairing $F 2$ 's ability to obtain capital market financing; 110 that consumers may refuse to buy $F 2$ 's products for fear that $F 2$ will not stand behind its warranties (or provide future parts and services); that $F 2$ may have difficulty obtaining trade credit; 111 that $F 2$ may impair its relationships with governmental entities; and that $F 2$ and its officers and directors may even become subject to criminal liability, including under the Racketeer Influenced and Corrupt Organizations Act ("RICO")."12 The more

106. I am not arguing that any of the claims against $F 2$ need succeed, only that they create a risk of liability in a context where (because recovery of the dividend from F1's shareholders is less likely) $F 2$ would be the most exposed deep pocket.

107. Cf. Janet Cooper Alexander, Do the Merits Matter? A Study of Settlements in Securities Class Actions, 43 STAN. L. REV. 497, 530 (1991) (arguing that directors and officers are invariably sued in their individual capacities, even when the entity defendants are fully able to respond in damages, in part because "they can be counted on to be powerful advocates for settlement because they are more risk-averse than the entity defendants"). Settlement would also let $F 2$ avoid paying counsel fees and suffering potentially adverse publicity.

108. Although $F 2$, like all businesses, takes ordinary business risks in order to earn profits, the risk associated with judgment proofing exceeds those ordinary risks. If $F 2$ is unable to assess correctly the judgment proofing risk, it may charge a risk premium. See FRANK H. EASTERBROOK \& DANIEL R. FISCHEL, THE ECONOMIC STRUCTURE OF CORPORATE LAW 52 (1991).

109. The term agency costs refers to costs resulting from the inherent conflict of interest between a firm and its managers. Managers, for example, want job security and high income whether or not those goals benefit the firm. See Michael C. Jensen \& William H. Meckling, Theory of the Firm: Managerial Behavior, Agency Costs and Ownership Structure, 3 J. FIN. ECON. 305, 308-10 (1976) (analyzing agency costs).

110. Rating agencies, such as Standard \& Poor's Ratings Group and Moody's Investors Service, Inc., might downgrade the debt rating of a company that helps another company become judgment proof because aiding and abetting a judgment proofing can expose a company to significant liabilities. See notes 207-227 infra and accompanying text (analyzing those liabilities). The downgraded company then will find it more difficult to issue debt securities to obtain capital market financing. See Alchemy, supra note 21, at 134 n.4, 136-38 (describing capital markets and rating agencies, and explaining the relationship between a company's debt rating and its ability to obtain capital market financing).

111. Trade credit, which is measured by the willingness of suppliers to extend goods and services to a company on credit, is essential to the successful operation of most businesses. See Mitchell a. Petersen \& Raghuram G. Rajan, TRADE CRedit: THEORIES ANd Evidence 1 (National Bureau of Econ. Research Working Paper No. 5602, 1996) (observing that "[t]rade credit is the single most important source of short term external finance for firms in the United States"); Foraging for Finance, CHEMIST \& DRUGGIST, Mar. 7, 1998, at 21, 22 ("Trade credit is an essential form of finance....").

112. Organized Crime Control Act of 1970 \$ 901(a), 18 U.S.C. $\$ \$ 1961-1968$ (1984 \& Supp. 1999). See notes 228-250 infra and accompanying text for a description of how RICO applies to judgment proofing. 
creditworthy $F 2$ is, the greater will be its reputational harm and therefore the higher will be its reputational costs. Thus, a low likelihood that $F 2$ will have to pay the financing premium referred to above ${ }^{113}$ is offset by a high likelihood that $F 2$ will require compensation to offset reputational costs.114

Agency costs will arise out of the risk that $F 2$ might go bankrupt as a result of becoming embroiled in a lawsuit by $F 1$ 's creditors, possibly causing $F 2$ 's managers to lose their jobs. 115 Those managers therefore will want $F 2$ to be paid greater compensation, which presumably would be channeled in whole or in part into management compensation. Some managers may even refuse to engage in the risk notwithstanding compensation.116 The more creditworthy $F 2$ is, the higher will be these agency costs because F2's managers will have more at stake in keeping their jobs. Thus, as before, a low likelihood that $F 2$ will have to pay the financing premium is offset by a high likelihood that $F 2$ will require compensation to offset agency costs. Also, whether or not $F 2$ is creditworthy, additional agency costs will arise because $F 2$ 's officers and directors are likely to want to avoid criminal liability under RICO and, because of the stigma, may even want to avoid being named in a lawsuit alleging $\mathrm{RICO}$ violations.

As a result of these costs, $F 2$ will require compensation, $\kappa$, that may well exceed $\Delta$. Moreover, whether or not $\kappa$ exceeds $\Delta, \kappa$ is even more likely to exceed the portion of $\Delta$ that $F 1$ would be willing to pay $F 2$ for the judgment proofing. It would be irrational for $F 1$ to offer compensation to $F 2$ that approaches $\Delta$, the value of $F 1$ 's assets.117 Delta is the most that $F 1$ could lose absent judgment proofing. Yet $F 1$ 's cost-saving from judgment proofing is speculative because $F 1$ 's operations may never give rise to material future involuntary claims. ${ }^{118}$

113. See note 97 supra and accompanying text.

114. Professor LoPucki discounts reputational costs as a constraint on judgment proofing, but his analysis is incomplete because it focuses only on the public relations costs of "typical business[es] with assets worth $\$ 500,000$ to $\$ 1$ million." Death of Liability, supra note 1, at 52-53.

115. See Easy Case, supra note 15, at 459-60 \& nn.154-57 (referring to two studies reporting that only a minority of incumbent corporate managers and directors remains in office following a corporate reorganization; none remains in office after a liquidation).

116. See Clayton P. Gillette, Commercial Relationships and the Selection of Default Rules for Remote Risks, 19 J. LEGAL STUD. 535, 561 (1990) ("If . . . investment in risky ventures can produce career-threatening losses, a manager is likely to avoid the risk, notwithstanding its expected value or its probability distribution.").

117. Recall that $\Delta$ is limited to the value of assets, whether owned or leased, that $F I$ uses in its business. See note 90 supra and accompanying text.

118. Cf. Lucian Arye Bebchuk \& Jesse M. Fried, The Uneasy Case for the Priority of Secured Claims in Bankruptcy: Further Thoughts and a Reply to Critics, 82 CORNELL L. REV. 1279, 1340 (1997) (arguing, among other things, that the transaction costs associated with setting up a parentsubsidiary strategy are borne $100 \%$ of the time whereas the strategy's liability-avoiding benefits are enjoyed only a small fraction of the time). To reduce the effect of speculation, I considered whether $F 1$ and $F 2$ would contract ex ante for compensation to be paid ex post based on the actual amount 
Judgment proofing also imposes its own set of costs on $F 1$, which $F 1$ would have to subtract from $\Delta$. I already have mentioned that $F 1$ would have to pay taxes on income derived from the sale of its assets to $F 2.119$ Judgment proofing also would take away $F 1$ 's ability to obtain liquidity and survive a troubled situation, 120 as a result of which unpaid liabilities can easily drive F1 into bankruptcy. Bankruptcy might subject Fl's shareholders to substantive consolidation and other equitable remedies.121 Bankruptcy also would impose particularly high agency costs because, having no assets with which to reorganize, $F 1$ almost certainly would liquidate in bankruptcy, depriving managers of their jobs. ${ }^{122}$ Furthermore, $F 1^{\prime}$ 's managers and directors may incur personal, and possibly criminal, liability for judgment-proofing the company. ${ }^{123}$ These costs detract from any value that $F 1$ otherwise would see in judgment proofing.

As an economic matter, therefore, arm's length judgment proofing is a dubious strategy. If $F 2$ is unable to finance the purchase of $F 1$ 's assets, the judgment proofing attempt would fail $a b$ initio. 124 Even where the financing is feasible, the ability of $F 1$ and $F 2$ to reach agreement on compensation is

of future involuntary claims. If the amount of those claims is small, the compensation would be small, but if the amount of those claims is large, the compensation also would be large. Such an agreement will not work, however, because $F l$ 's obligation to pay compensation is directly proportional-whereas its financial ability to pay compensation is inversely proportional-to the amount of those claims. Thus, in the case where compensation is large, $F l$ will have no ability to pay it.

119. See notes 53-54 supra and accompanying text (discussing tax treatment of an arm's length sale-leaseback transaction).

120. See White, supra note 10, at 1397 (arguing that a judgment proofed firm would have "trouble meeting its interest and principal obligations any time it suffered losses for even a short period").

121. See notes 185-199 infra and accompanying text (discussing shareholder risk of substantive consolidation, especially where shareholders participate in the judgment proofing such as by guarantying $F I$ 's lease obligations).

122. Viewed from the standpoint of a manager wanting to keep her job, ensuring that the company will be able to continue operating during a downturn is a more important incentive than maximizing shareholder value through judgment proofing. Of course, $F I$ could offer its managers a portion of $\Delta$ as compensation for the risk, but the larger the portion offered, the less available to pay to $F 2$ as compensation.

123. See John C. Coffee, Jr., Shareholders Versus Managers: The Strain in the Corporate $W e b, 85$ MiCH. L. REV. 1, 18 \& n.46, 19 (1986) (citing examples where corporate managers were sued as a result of taking actions that led to insolvency or corporate distress); see also notes 228250 infra and accompanying text (discussing the application of RICO to judgment proofing).

124. On the other hand, the innovative arm's length business transactions that are alleged to lead to judgment proofing actually can lead to increased efficiency. Asset securitization, for example, enables companies to obtain lower-cost financing than they would otherwise be able to obtain. See Alchemy, supra note 21, at 134, 140; Frost, supra note 21, at 129 (arguing that inefficiencies involved with banknuptcy reorganizations are among the reasons why securitization allows for lower-cost financing than the simpler approach of secured finance and that securitization produces real savings that could be shared by all investors). 
questionable125 because the value of judgment proofing to $F 1$ may well be less than the costs it would impose on $F 2.126$

These economic conclusions are strengthened by observations from social psychology. Because economic analysis alone is sometimes not an accurate predictor of human behavior, 127 I have considered how people may behave when confronted with risky decisions. A leading model of such behavior, "prospect theory," 128 predicts that individuals who are performing above the success level that they seek to achieve (their "aspiration level") will prefer lower risk options, rather than comparing the expected values of different alternatives.129 Thus, so long as F2's managers are operating the company at their aspiration level—which Professor Coffee defines as "that

125. This is not to say that in individual cases judgment proofing will not occur. People do take risks and often act irrationally. Nonetheless, without evidence to the contrary, one should not assume that irrationality will be systematic.

126. Professor LoPucki has suggested, however, that as more companies engage in judgment proofing, its costs will decline and it will become more prevalent. See Death of Liability, supra note 1 , at $44-45$. My analysis does not indicate that any of those costs, other than possibly reputational cost, is likely to decline. Certainly the most significant cost, potential liability to FI's creditors, would be completely unaffected.

127. "[E]xpected utility theory is not a good description of actual decisionmaking." Jolls et al., supra note 8 , at 1478 .

128. "There has been an explosion of research in recent years trying to develop better formal models of actual decisionmaking. The model offered by Kahneman and Tversky, called prospect theory, seems to do a good job of explaining many features of observed behavior ...." Id. at 1478 . Prospect theory is an outgrowth of subjective expected utility theory, which itself augments expected utility theory by taking into account subjective value and risk to the decision-maker. See generally Lola L. Lopes, Psychology and Economics: Perspectives on Risk, Cooperation, and the Marketplace, ANN. REV. PSYCHOL., Jan. 1, 1994, at 197.

129. See generally Peter C. Fishburn, Mean-Risk Analysis with Risk Associated with BelowTarget Returns, 67 AM. ECON. REV. 116 (1977) (describing models for choice among investment options that predict a strong effect of target returns); Daniel Kahneman \& Amos Tversky, Prospect Theory: An Analysis of Decision Under Risk, 47 ECONOMETRICA 263 (1979) (introducing prospect theory); Amos Tversky \& Daniel Kahneman, Advances in Prospect Theory: Cumulative Representation of Uncertainty, 5 J. RISK \& UNCERTAINTY 297 (1992) [hereinafter Advances in Prospect Theory] (developing cumulative prospect theory and introducing the theory of loss aversion); John W. Payne, Dan J. Laughhunn \& Roy Crum, Translation of Gambles and Aspiration Level Effects in Risky Choice Behavior, 26 MGMT. SCI. 1039 (1980) (extending Kahneman \& Tversky's model to incorporate a target point reference); John W. Payne, Dan J. Laughhunn \& Roy Crum, Further Tests of Aspiration Level Effects in Risky Choice Behavior, 27 MGMT. SCI. 953 (1981) (further extending the target point model). For examples of applications of prospect theory to corporate decisionmaking, see also Coffee, supra note 123, at 64-66. Studies have found that individuals will prefer higher risk options when they are performing below their aspiration level: "[I]ndividuals move from being risk preferrers to risk averters, or vice versa, depending on whether they are performing above or below their aspiration level." Id. at 64; see also John W. Payne, Dan J. Laughhunn \& Roy Crum, Managerial Risk Preferences for Below-Target Returns, 26 MGMT. SCI. 1238, 1246 (1980) (considering the impact of ruinous loss considerations on risk preferences); James D. Cox, Heroes in the Law: Alford v. Shaw, 66 N.C. L. REv. 565, 578 (1988) (arguing that when the predicted outcomes of most of the choices confronting managers fall below their desired target level, the managers will "select the more risky options out of an apparent hope they may be able to achieve a result above the target point"). 
level of profits that protect[s] [management] from ouster"130 - they will seek to avoid the high risks associated with judgment proofing $F 1$. While there will be cases where $F 2$ 's managers are performing below their aspiration level, 131 judgment proofing $F 1$ for compensation will be only one of many high-risk strategies that the managers might consider. Because the foregoing economic analysis has shown it to be an economically dubious strategy and one that introduces other risks of job loss as well as of criminal liability, judgment proofing even then is unlikely to be the strategy of choice. ${ }^{132}$

A further development of prospect theory, referred to as "loss aversion," confirms that arm's length judgment proofing is unlikely to succeed.133 Research has shown that people's risk attitudes toward a particular task depend on whether they perceive a potential gain or loss from engaging in the task. Tasks for which a person perceives potential gains typically produce riskaverse behavior, whereas tasks for which a person perceives potential losses yield risk-seeking behavior. ${ }^{134}$ For example, 135 if someone has a choice between, on the one hand, a sure gain of $\$ 50$ and, on the other hand, a $50 \%$ chance of winning $\$ 100$ and a $50 \%$ chance of winning nothing, he will take the sure gain, even though the expected value of both choices is equal.136 But if that same person is put to a choice between, on the one hand, a sure loss of $\$ 50$ and, on the other hand, a $50 \%$ chance of losing $\$ 100$ and a $50 \%$

130. Coffee, supra note 123 , at 65 (applying prospect theory to management decision making).

131. Professor Coffee has queried whether the advent of hostile takeovers has caused senior managers of "large public corporations" to "subjectively feel that they are performing below the necessary level of profitability that will protect them from ouster." Id. If $F 2$ is a large public corporation, however, the reputation costs of judgment proofing would be extremely high, whereas the amount of compensation that $F 2$ could derive therefrom would probably have an insignificant impact on $F 2$ 's profitability. It therefore is unlikely that $F 2$ would be a large public corporation.

132. Professor Langevoort has suggested that corporations typically undertake projects posing ambiguous initial risks with a commitment to monitor the project, so that it can be abandoned at relatively low cost should difficulties or risks surface. See Langevoort, supra note 8, at 165-66. Judgment proofing, however, is not such a project: The ambiguity of risk remains until the judgment proofing is challenged, at which point the costs may be very high and unavoidable. Furthermore, if $F 2$ is so unprofitable that its managers are in danger of ouster, it seems unlikely that $F 2$ would have the financial wherewithal to purchase FI's assets in the sale-leaseback that precedes a judgment proofing.

133. See Advances in Prospect Theory, supra note 129, at 298 (defining "loss aversion" as a basic phenomenon of choice in which "losses loom larger than gains").

134. See Linda Babcock, Henry S. Farber, Cynthia Fobian \& Eldar Shafir, Forming Beliefs About Adjudicated Outcomes: Perceptions of Risk and Reservation Values, 15 INT'L REV. L. \& ECON. 289, 290, 296-97 (1995); Thomas S. Ulen, Firmly Grounded: Economics in the Future of the Law, 1997 WIS. L. REV. 433, 459-60 (1997).

135. The author is grateful to Professor Thomas Ulen for suggesting these examples. See electronic mail from Thomas Ulen, Alumni Distinguished Professor of Law, University of Illinois at Urbana-Champaign, to Steven L. Schwarcz (Oct. 20, 1998) (on file with author).

136. The expected value of the sure gain is $\$ 50(\$ 50 \times 100 \%)$. The expected value of the possibility of winning also is $\$ 50(\$ 100 \times 50 \%+\$ 0 \times 50 \%)$. 
chance of losing nothing, he will prefer the possibility of loss over the sure loss even though, again, the expected value of both choices is equal.137

Arm's length transactions are voluntary. $F 2$ therefore would enter into an arm's length judgment proofing transaction, if at all, solely for gain. Hence, the doctrine of loss aversion predicts that $F 2$ would be risk averse in negotiating the terms of that transaction. F2's risk aversion would raise the amount of compensation that $F 2$ would demand, thereby decreasing the likelihood that $F 1$ and $F 2$ will be able to agree on a mutually acceptable level of compensation. ${ }^{138}$

I next show, however, that judgment proofing is more likely to be a concern in the structuring of non-arm's length transactions.

\section{The Structuring of Non-Arm's Length Business Transactions Is More Likely to Give Rise to Judgment Proofing}

Non-arm's length judgment proofing transactions can be represented by a generic structure in which $F 1$ (the company being judgment proofed) and $F 2$ (the company helping to judgment proof $F 1)^{139}$ are now related by common ownership through a third entity, $F 3.140 F 3$ may be a company, an individual, or any other entity; for simplicity, I will refer to $F 3$ as a company, but the same consequences flow irrespective of F3's actual identity. This ge-

137. The expected value of the sure loss is $\$ 50$ ( $\$ 50 \times 100 \%)$. The expected value of the possibility of losing also is $\$ 50(\$ 100 \times 50 \%+\$ 0 \times 50 \%)$.

138. Although one case superficially appears to represent an arm's length judgment proofing transaction, the actual judgment proofing transfer was clearly not arm's length. In Schmoll $v$. Acands, Inc., 703 F. Supp. 868 (D. Or. 1988), aff'd 977 F.2d 499 (9th Cir. 1992), Raymark Industries Inc. attempted to avoid asbestos-related liability by engaging in an "elaborate transfer of assets," id. at 873, with the final transfer being made to an apparently independent company, Asbestos Litigation Management ("ALM"), see id. at 871. A close analysis, however, shows that the final transfer was not essential to the judgment proofing. Rather, the judgment proofing was consummated by the next-to-last transfer, which occurred when Raytech Corporation, the indirect owner of $100 \%$ of Raymark's shares, caused Raymark to sell its valuable assets to Raytech for inadequate consideration, consisting primarily of worthless stock and unsecured promissory notes of Raytech. See id. at 871-72 (describing step five of the six-part judgment proofing transaction, after which Raytech owned all of Raymark's valuable assets while Raymark retained all of the asbestos-related liabilities). The final, and only arguably arm's length, transfer consisted of a sale by Raytech to ALM of the stock of Raymark. That sale, however, apparently was undertaken merely to sever the corporate chain between Raytech and Raymark and did not worsen the ability of asbestos claimants to recover their claims from Raymark. In any event, a court in subsequent related litigation found that Raytech and ALM were related by certain common management and stock ownership and questioned whether the final transfer was actually arm's length. See Raytech Corp. v. White, 54 F.3d 187, 194 (3d Cir. 1995) (questioning the "bona fides of the sale of Raymark to ALM").

139. As before, the same overall consequences would obtain if $F 2$ represented more than one company. I therefore only need to refer to a "collective" $F 2$ in the generic structure.

140. If $F 1$ and $F 2$ are owned by $F 3, F 1$ and $F 2$ would be referred to as "sister companies." Alternatively, $F 3$ could own $F 2$, which in turn owns $F 1$. 
neric structure incorporates the parent-subsidiary ownership structure previously discussed141 as well as LoPucki's "essential structure."142

There are two approaches by which non-arm's length transactions could be used for judgment proofing. In one approach, $F 3$ establishes $F 1$ as an undercapitalized operating company and causes $F 2$ to acquire assets to be used by $F 1.1^{143} F 2$ then leases those assets to $F 1$. Alternatively, if $F 1$ already owns its operating assets, $F 3$ could cause $F 1$ to sell those assets to $F 2$ and to lease them back. In either case, the structure creates a risk of judgment proofing in which $F 1$ 's operations have the potential for generating liabilities that $F 1$, with its minimal owned assets, would be unable to pay.144

Non-arm's length transactions are more likely than arm's length transactions to be entered into for judgment proofing. If $F 1$ and $F 2$, which are related companies, are part of the same consolidated tax group, a saleleaseback between them will not be subject to federal taxation. ${ }^{145}$ Moreover, whereas arm's length transactions involve unrelated companies which try to maximize the value each will receive from a transaction, related companies may want to maximize their aggregate corporate wealth, thereby making judgment proofing easier. To understand why, compare the earlier analysis of unrelated companies, again letting $\Delta$ stand for the amount of value that

141. The parent-subsidiary ownership structure is simply the generic structure taking away $F 2$, so that $F 3$ owns only $F 1$. The only difference that would make to my analysis is that $F 3$ would be an active participant in judgment proofing $F 1$ and therefore may be subject to greater liability than in the generic structure. Judgment proofing is therefore more likely to occur in the generic structure than in the simple parent-subsidiary ownership structure.

142. Recall that LoPucki's "essential structure" is a "symbiotic relationship between two or more entities [represented by $F 1, F 2$, and $F 3$ in my generic non-arm's length structure], in which one of the entities [F1] generates disproportionately high risks of liability and another [F2] owns a disproportionately high level of assets. Through the contract that unites them [F3's mutual ownership of $F I$ and $F 2$ ], the two entities allocate between them the gains from judgment proofing." Essential Structure, supra note 2, at 149.

143. F2 already may be sufficiently capitalized to acquire these assets. If not, $F 2$ could acquire the assets from the proceeds of a stock offering or borrowing. I previously argued, in an arm's length context, that $F 2$ would have difficulty borrowing if $F 1$ is judgment proof. See note 96 supra and accompanying text. In a non-arm's length context, however, $F 3$ (if creditworthy) could make it easier for $F 2$ to borrow by guaranteeing $F 2$ 's repayment obligation.

144. That risk would be minimized if FI's directors have an obligation to consider the company's potential future involuntary creditors. See notes 200-206 infra and accompanying text (discussing the risk of judgment proofing if directors have no obligation to future involuntary creditors).

145. If $F 1$ and $F 2$ are part of an "affiliated" group-which roughly requires at least $80 \%$ common ownership, with a common parent corporation (F3 in my example)-that files consolidated returns, then the gain on sale may be deferred for federal income tax purposes. See I.R.C. $\S \S$ 1502-1504 (1988 \& Supp. 1999); Treas. Reg. $§ 1.1502-13$ (as amended in 1997). In contrast, F1 would have to pay federal taxes on the income from a sale of assets to an unrelated $F 2$. See note 54 supra and accompanying text (discussing taxation of an arm's length sale-leaseback transaction). Even in a non-arm's length structure, however, there may be recognition of gain for state income tax purposes if combined reporting is not permitted under the applicable state law. 
judgment proofing takes from $F 1$ 's creditors. ${ }^{146}$ If $F 1$ and $F 2$ are unrelated, $F 1$ would attempt to judgment proof itself only so long as the amount of compensation that $F 2$ would require to help it do so is less than $\Delta .147$ I have shown, however, that that amount of compensation may well exceed $\Delta$ and is even more likely to exceed the portion of $\Delta$ that $F 1$ would be willing to pay, making arm's length judgment proofing unlikely to occur. ${ }^{148}$ In contrast, if $F 1$ and $F 2$ are related, their mutual shareholder, $F 3$, could request $F 2$ to help in the judgment proofing whether or not $F 2$ is separately compensated.149 Thus, the previous analysis of whether $F 1$ and $F 2$ could agree on compensation is irrelevant. Instead, non-arm's length judgment proofing would be rational so long as its benefit, $\Delta$, exceeds any cost to $F 1, F 2$, and $F 3$.

To determine whether $\Delta$ exceeds the cost to $F 1, F 2$, and $F 3$, we must again examine the costs of judgment proofing, now in a related-company context. Although it might appear that all of FI's and F2's costs, previously discussed in an arm's length context, ${ }^{150}$ would be applicable, the following analysis shows that only some of those costs would apply. On the other hand, $F 3$ itself may incur direct costs.

The financing premium discussed in an arm's length context151 might be less likely to apply in a non-arm's length transaction. Moreover, F2's potential liability to $F I$ 's future involuntary creditors may represent a relatively small cost if $F 3$, the common owner of $F 1$ and $F 2$, prefers the possibility of liability against $F 2$ to the greater certainty of liability against $F 1.152$ Al-

146. See note 78 supra and accompanying text.

147. See id.

148. Therefore unrelated-company judgment proofing is unlikely to occur. See notes $117-118$ supra and accompanying text.

149. F2's directors generally have an obligation to maximize value for the shareholder, $F 3$. See Pepper v. Litton, 308 U.S. 295, 306 (1939). Judgment proofing $F I$ arguably would accomplish that. Nonetheless, there may be doubt as to the obligations of $F 2$ 's directors. F3's value would be partly generated from the increased value of F1's shares, and it is unclear whether a director has an obligation to maximize shareholder value by taking steps that would increase the value of stock held by the shareholder in other companies. Furthermore, if $F 2$ is rendered insolvent, $F 2$ 's directors may be violating their dual fiduciary obligation to F2's creditors. See notes 200-206 infra and accompanying text.

150. See notes 93-126 supra and accompanying text (examining the costs of arm's length judgment proofing).

151. See notes 93-97 supra and accompanying text (discussing the financing premium in an arm's length context). There are several reasons why $F 2$ might be able to avoid paying that premium in a non-arm's length transaction. If a creditworthy $F 3$ guarantees $F 2$ 's financing obligations, the financier might waive the premium. $F 3$ itself might be able to finance $F 2$ directly (raising the issue, of course, of whether $F 3$ must pay a premium for its own financing). Ultimately, the applicability of a financing premium will be a question of fact.

152. See notes 207-220 infra and accompanying text (discussing why $F 2$ may become liable to $F 1$ 's creditors). Whether $F 3$ prefers the possibility of liability against $F 2$ to the greater certainty of liability against $F 1$ will depend, among other factors, on the relative values of $F 1$ and $F 2$. All other factors being equal, the smaller $F 2$ 's value compared to $F 1$ 's value, the more likely that $F 3$ will try to shift the risk to $F 2$. 
though $F 1$ and $F 2$ still will suffer reputation and agency costs, those costs, if confined to $F 1$ and $F 2$, may be relatively unimportant. For example, $F 3$ might not care about $F 1$ 's or $F 2$ 's reputation so long as its own reputation is unaffected. And if $F 1$ or $F 2$ is forced to liquidate, its officers may well be able to find jobs with $F 3$.

$F 3$ also may become directly subject to claims by $F 1$ 's creditors, through the doctrines of piercing the corporate veil and substantive consolidation, for example.153 Furthermore, F3's officers and directors might be concerned about the risk of criminal liability under RICO.154 Nonetheless, the likelihood that $F 3$ and its officers and directors will become subject to liability might be somewhat attenuated if $F 3$ 's involvement in the judgment proofing is passive rather than (as F2's involvement would be) direct and active.155 For example, in Eastgroup Properties v. Southern Motel Assoc., Ltd.,156 a case involving a judgment proofing structure that resembles this article's generic $F 1-F 2-F 3$ structure, a court extended $F 1$ creditor liability against the company representing $F 2$ but did not consolidate the entities representing F3.157

Because $F 3$ is uncertain whether it will be subject to liability, it cannot know ex ante in a non-arm's length judgment proofing whether $\Delta$ will exceed costs. Social psychology predicts, however, that related companies, such as $F 1, F 2$, and $F 3$, will be risk prone. Recall that the doctrine of loss aversion demonstrates that potential gains produce risk-averse behavior but potential losses produce risk-seeking behavior. ${ }^{158}$ In an arm's length transaction, $F 2$ would engage in judgment proofing solely for gain, in the form of compensation. Therefore $F 2$ would be risk averse. 159 But in a non-arm's length transaction, $F 3$ would try to avoid losses from future involuntary claims. Because $F 3$ owns $F 1$, any loss to $F 1$ represents a loss to $F 3.160$ Loss

153. See notes 179-199 infra and accompanying text (explaining why $F 3$ may become liable to $F$ l's creditors under those doctrines).

154. See notes 228-250 infra and accompanying text (describing the application of RICO to judgment proofing).

155. F3's involvement would not be passive, however, where it guarantees FI's lease obligations.

156. 935 F.2d 245 (11th Cir. 1991).

157. See note 196 infra (discussing Eastgroup Properties v. Southern Motel Assoc., Ltd. and noting that the issue of whether $F 3$ should be consolidated did not even appear to be raised).

158. See note 133 supra and accompanying text.

159. See note 138 supra and accompanying text.

160. To say that $F 3$ is avoiding losses depends, of course, on F3's perspective, which ultimately is subjective. Assume, for example, that the expected value of future involuntary claims against $F 1$ is $\$ X . F 3$ logically would engage in judgment proofing, if at all, in order to avoid that loss. It is not inconceivable, however, that some $F 3$ s might implicitly deduct $\$ X$ from $F 1$ 's value based on the expectation of future claims. Those F3's would view judgment proofing as creating a gain of $\$ X$, and therefore would be risk averse. A crude analogy might be made to the shopping philosophy of the Dickens character, Richard Jamdyce, who, when dissuaded "from making any 
aversion predicts that $F 3$ will be more likely to take risks to avoid those losses. 161 Thus, judgment proofing is more likely to occur in a non-arm's length than in an arm's length context.

Nonetheless, where existing law fails as an ex ante deterrent to judgment proofing, it still may have an ex post remedial impact by requiring $F 2$ and $F 3$ to pay $F 1$ 's liabilities. I next analyze how judgment proofing is regulated.

\section{Regulation of Judgment Proofing Under Existing Law}

Existing law regulates judgment proofing in two ways. It restricts the ability of insolvent companies to give away their assets, thereby limiting a company's (in this case, $F 1$ 's) ability to judgment proof itself. It also imposes costs on the parties (in this case, $F 1, F 2$, and, in the case of non-arm's length judgment proofing, $F 3$, as well as their officers, directors, and possibly shareholders) participating in the judgment proofing, such as by making them potentially liable to $F 1$ 's creditors. Of special relevance in this context are bankruptcy law (fraudulent conveyance and substantive consolidation), corporate law (piercing the corporate veil and the duties of directors), tort law (lender liability and prima facie torts), and criminal law (including RICO).

Fraudulent conveyance law, which generally restricts the ability of insolvent companies to dispose of their assets for less than reasonably equivalent value, ${ }^{162}$ represents the first-and arguably also the second163-type of

purchase that he had in contemplation which was particularly unnecessary and expensive ... took credit for what it would have cost and made out that to spend anything less on something else was to save the difference." CHARLES DICKENS, BLEAK HOUSE 261 (Stephen Gill ed., Oxford Univ. Press 1996) (1853).

161. F3's increased propensity to take risks is suggested by the similarity between F3's choices and the choices of subjects in loss-aversion experiments. In a typical such experiment, subjects, initially "given" $\$ 500$, were offered a choice between $(x)$, a $50 \%$ chance to lose $\$ 200$ and a $50 \%$ chance to lose nothing, and $(y)$, a sure loss of only $\$ 100$. Sixty-four percent of the subjects chose $(x)$, the riskier option; only $36 \%$ chose $(y)$, the more conservative option. See RICHARD H. THALER, QUASI RATIONAL ECONOMICS 143 (1991) (describing loss-aversion experiments conducted by Professors Tversky and Kahneman). In my hypothetical, $F 3$ has the choice between not judgment proofing, which represents a sure loss equal to the amount of future involuntary claims, and judgment proofing, which represents a chance of losing more than the amount of future involuntary claims (due to potential punitive damages and criminal liability) and a chance of losing nothing. Although the analogy obviously is imprecise because F3's choice will depend on the numbers associated with these variables, it at least suggests that under a range of numbers, $F 3$ might be willing to choose the former, riskier option.

162. Fraudulent conveyance law is both federal and state law. The federal law is articulated in the Bankruptcy Code, 11 U.S.C. § 548(a)(1) (1993 \& Supp. 1999), in part as follows:

The trustee [in bankruptcy] may avoid any transfer of an interest of the debtor in property ... that was made or incurred on or within one year before the date of the filing of the [bankruptcy] petition, if the debtor voluntarily or involuntarily- 
regulation. ${ }^{164}$ To understand how it represents the first type of regulation, consider the hypothetical in which $F 1$ attempts to judgment proof itself by transferring its assets to $F 2 .{ }^{165}$ If that transfer is made with actual intent (as would appear to be the case with judgment proofing) to hinder, delay, or defraud $F 1$ 's creditors-or, even absent such intent, if such transfer leaves $F 1$ with insufficient assets to pay its debts and $F 1$ does not receive reasonably equivalent value in return-the transfer could be avoided under fraudulent conveyance law whether $F 1$ and $F 2$ are related or unrelated companies. 166 Fraudulent conveyance law even explicitly protects future creditors, whose claims are not in existence at the time of the transfer. ${ }^{167}$ Moreover, fraudulent conveyance law applies to any kind of transfer, including payment of

(A) made such transfer ... with actual intent to hinder, delay, or defraud any entity [that is, any creditor] to which the debtor was or became, on or after the date that such transfer was made...., indebted; or and

(B)(i) received less than a reasonably equivalent value in exchange for such transfer ...;

[either was insolvent or had an unreasonable small capital or intended to incur, or believed it would incur, debts beyond its ability to pay as such debts matured].

Fraudulent conveyance law also is articulated in state law in three general forms: common law dating back to the sixteenth century English Statute of Elizabeth, An Acte agaynst fraudulent Deedes Gyftes Alienations, \&c., 13 Eliz., ch. 5 (1571) (Eng.); uniform state law based on the Uniform Fraudulent Conveyance Act, which remains in effect in six states, see James J. Cunningham \& Marsha E. Simms, Acquisition Financing, in PRACTISING LAW INSTITUTE, ASSET-BASED FINANCING 387, 400 (1998); and uniform state law based on the more recent Uniform Fraudulent Transfer Act, which is in effect in 37 states, see id. Most state fraudulent conveyance laws are based on the Uniform Fraudulent Transfer Act, which is intended to be consistent with Bankruptcy Code $\$ 548$. See id. I therefore will focus on $\S 548$.

163. See notes 171-173 infra and accompanying text (arguing that fraudulent conveyance law also represents the second type of regulation because it may require $F 2$ to return to $F 1$ the assets that $F 2$ purchases in a sale-leaseback transaction).

164. This regulation is not unlimited, however. Fraudulent conveyance law is subject to a statute of limitations of one year under federal law, see 11 U.S.C. $\S 548$ (a)(1) (1993 \& Supp. 1999), and usually longer under state law (four years for states following the Uniform Fraudulent Transfer Act, six years for those following the Uniform Fraudulent Conveyance Act). Thus, in the unlikely event that a judgment-proofed company survives past the longest applicable statute of limitations, typically four to six years, the act of judgment proofing no longer would be subject to avoidance as a fraudulent conveyance. Nonetheless, the analysis below shows that other legal restrictions could then apply.

165. See notes 79-91 supra and accompanying text.

166. See Rubin v. Manufacturers Hanover Trust Co., 661 F.2d 979 (2d Cir. 1981) (observing that federal fraudulent transfer law can void transfers between related companies). If $F I$ does receive reasonably equivalent value, it could then judgment proof itself by turning that value over to its shareholders in the form of a dividend.

167. Section 548(a)(1)(A) specifically provides that the trustee may avoid any transfer if the debtor made such transfer with "actual intent to hinder, delay, or defraud any entity to which the debtor ... became [indebted] on or after the date that such transfer was made." 11 U.S.C. $\S$ 548(a)(1)(A) (1993 \& Supp. 1999) (emphasis added). Sections 548(a)(1)(B)(ii)(II) and (III) apply, respectively, to debtors about to engage in business or transactions for which their property remaining is an unreasonably small capital and to debtors intending to incur, or believing they will incur, debts that are beyond their ability to pay as such debts mature. 
dividends 168 - the kind of transfer that I show is the real problem in judgment proofing. 169 Thus, fraudulent conveyance law limits $F 1$ 's ability to judgment-proof itself in the first place. 170

Fraudulent conveyance law also could represent the second type of regulation, one which imposes costs on a party participating in the judgment proofing -in this case, on $F 2$. The rationale underlying a leading fraudulent conveyance case, United States v. Tabor Court Realty Corp. (In re Gleneagles Investment $\mathrm{Co}$.), ${ }^{171}$ would require $F 2$ to return to $F 1$ the assets that $F 2$ purchases in a sale-leaseback transaction-even if $F 2$ had paid reasonably equivalent value for them. That return would impose a cost on $F 2$ because it would be unable to recover the purchase price from $F 1$, which is judgment proof. ${ }^{172}$ In Tabor, a financial institution which made a loan as part of a leveraged buyout "knew, or should have known, that the money it lent . . . was used, in part, to" pay shareholders of the borrower.173 The Third Circuit agreed with the district court's finding that the loan and the subsequent payment of loan proceeds to shareholders were "part of one integrated transaction" and held that, under state fraudulent conveyance law, the " $\$ 4,085,000$ in . . . loan proceeds ... were merely passed through the [borrower to its ultimate shareholders] and cannot be deemed consideration received by the

168. See, e.g., In re Dondi Fin. Corp., 119 B.R. 106, 113 (Bankr. N.D. Tex. 1990) (holding that "a dividend payment made while the debtor corporation was insolvent is a fraudulent conveyance" under state fraudulent conveyance law); In re Kaiser Steel Corp., 87 B.R. 154, 161 (Bankr. D. Colo. 1988) (holding that "the allegations set forth in Kaiser's amended complaint [that payment of dividends was a fraudulent transfer under the constructive fraud provisions of $\S 548$ of the Bankruptcy Code as well as under state fraudulent conveyance law] are sufficient to state claims for relief" under such laws); In re Jenkins Landscaping \& Excavating, Inc., 93 B.R. 84, 88 (Banis. W.D. Va. 1988) (voiding dividends issued with intent to defraud creditors); Powers v. Heggie, 167 N.E. 314, 317 (Mass. 1929) (holding that dividend payments by insolvent corporations are fraudulent); COX ET AL., supra note 59, § 20.26, at 20.76 \& n.13 (arguing that "[d]ividends as well as share repurchases made by an insolvent corporation easily fit within the proscription of' fraudulent conveyance law, and that "[t]he shares of a corporation on the verge of insolvency are of very little, if any, value, so distribution of a dividend to stockholders is presumed to lack fair equivalency"); William T. Vukowich, Civil Remedies in Bankruptcy for Corporate Fraud, 6 AM. BANKR. INST. L. REV. 439, 444-45 (1998) (observing that "state corporation laws and fraudulent conveyance law generally protect creditor interests by prohibiting dividend payments that would render a corporation insolvent. Furthermore, fraudulent transfer law and some states' corporation laws might offer even greater protection.").

169. See text accompanying note 65 supra (observing that to make itself judgment proof, Exxon would have to distribute its cash to its shareholders); White, supra note 10, at $1375 \mathrm{n} .49$ (acknowledging that "to judgment proof [a debtor] requires a second step, namely the disposition of the net proceeds [of the judgment proofing transfer] by dividends to shareholders").

170. See White, supra note 10, at 1403-04 (arguing that "fraudulent conveyance law provides a potential obstacle" to judgment proofing through subsidiaries).

171. 803 F.2d 1288 (3d Cir. 1986).

172. This cost ordinarily would be much higher in an arm's length transaction than in a nonarm's length transaction. In the former, $F 2$ would have no way to recover its loss; in the latter, the cost would merely be a reallocation of assets within a group of related companies.

173. Tabor, 803 F.2d at 1295 . 
[borrower]."174 As a result, the court voided mortgages granted by the borrower to secure the loan.175 In a judgment proofing transaction, a court might apply similar reasoning: that the sale-leaseback between $F 1$ and $F 2$, and Fl's subsequent payment of the sale proceeds to its shareholders, are part of a single integrated transaction; that $F 1$ therefore did not receive reasonably equivalent value for the assets sold to $F 2$; and thus those assets must be returned to $F 1$.

Fraudulent conveyance law does not, however, protect against the use of structures in which $F 1$, the operating company, is undercapitalized at its creation. Because there is no transfer of assets, fraudulent conveyance law does not apply.176 This problem can be illustrated by the hypothetical in which $F 1$ is established as an operating company with minimal assets, F2 acquires assets that $F 1$ wishes to use, and $F 2$ leases those assets to $F 1.177$ This structure creates a risk of judgment proofing because $F I$ 's operations have the potential for generating liabilities that $F l$, with its minimal owned assets, would be unable to pay. 178

Nonetheless, another provision of bankruptcy law, which represents the second way in which existing law regulates judgment proofing, 179 not only applies to undercapitalized related-company structures but also to any related-company structure. 180 Assume that $F 1$, the operating company, is un-

174. Id. at 1302. Although the court's holding is technically limited to Pennsylvania's enactment of the Uniform Fraudulent Conveyance Act, the court emphasized that Act's similarity to $\S$ 548 of the Bankruptcy Code. Id. at 1298-99.

175. See id. at 1305 (affirming the district court's ruling on this issue without commenting on the borrower's obligation to repay the loan).

176. There would be an anomaly if the law restricted judgment proofing caused by asset transfers but not judgment proofing resulting from related-company structures in which the operating company is undercapitalized at its creation. I later show that the anomaly does not exist because substantive consolidation law and the doctrine of piercing the corporate veil protect against the latter form of judgment proofing. See notes 175-179 and 194-196 infra and accompanying text.

177. See notes 179-199 infra and accompanying text.

178. That risk would be minimized if Fl's directors have an obligation to consider its potential future involuntary creditors. See notes 204-206 infra and accompanying text (discussing the risk of judgment proofing if directors have no obligation to future involuntary creditors).

179. That is, regulation that imposes potential liability on parties participating in the judgment proofing. See note 162 supra and accompanying text.

180. In this context, Professor Bermie Black raises a related question-Why don't companies simply operate with debt-heavy capital structures, which would soft judgment proof them as well as provide large tax advantages?-and asks whether answering that question would help to explain judgment proofing. He suggests three disincentives to debt-heavy capital structures: A debt-heavy company $(x)$ might find capital markets closed when it most needs them, $(y)$ might motivate equity holders to take risky gambles with creditor funds, to which creditors respond by not lending or by insisting on covenants that strictly limit financial flexibility, and (z) is more likely to need financial restructuring, to which creditors again respond by not lending. See electronic mail from Bernard Black, Professor of Law, Stanford University School of Law, to Steven L. Schwarcz 2 (Mar. 7, 1999) (on file with author). These disincentives do not, however, address the motivation of $F 2$ in an arm's length judgment proofing; and a non-arm's length judgment proofing structure-in which, for example, $F I$ operates with a debt-heavy capital structure while its equity owner, $F 3$, borrows for 
able to pay its creditors. Those creditors could force $F I$ into bankruptcy 131 and then could rely on the equitable power of a bankruptcy judge to order a "substantive consolidation" of $F 1, F 2$, and even $F 3.182$ A substantive consolidation "involves the pooling of the assets and liabilities of two or more related entities; the liabilities of the entities involved are then satisfied from the common pool of assets created by consolidation." 183 Thus, the claims of $F 1$ 's creditors would be satisfied from $F 2$ 's, and potentially also $F 3$ 's, assets. 184 In the latter case, $F 1$ 's creditors would have the right to claim against all of F3's assets, not merely assets that $F 3$ should have contributed as capital to $F 1$. F3 therefore could become significantly worse off than if it adequately capitalized $F 1$ in the first place.

Substantive consolidation also has limited application to an arm's length judgment proofing transaction. Although it would not apply to the transaction between the unrelated parties, $F 1$ and $F 2$, it could restrict $F 1$ 's shareholders from participating in the judgment proofing, such as where $F I$ judgment proofs itself by distributing its assets to shareholders, 185 or where shareholders of an undercapitalized $F 1$ induce $F 2$ (such as by guaranteeing the lease rentals) to lease assets to $F 1$. In either case, $F 1$ 's creditors could seek to consolidate the assets of those shareholders, even if those shareholders are not themselves in bankruptcy. ${ }^{186}$

Fl (or guaranties Fl's borrowing)-could avoid each of these disincentives. Professor Black's question nonetheless is important. I attempt to address it in the larger context of analyzing judgment proofing by undercapitalization, a debt-heavy capital structure being merely one way that a company could operate while undercapitalized.

181. See 11 U.S.C. $\S 303$ (1993 \& Supp. 1999) (discussing involuntary bankruptcy filings).

182. See 11 U.S.C. $\$ 105$ (1993) (stating that a bankruptcy judge has the power to "issue any order, process, or judgment that is necessary or appropriate to carry out the provisions of' the Bankruptcy Code).

183. Eastgroup Properties v. Southern Motel Assoc., 935 F.2d 245, 248 (11th Cir. 1991). Even though $F 2$ is not itself in bankruptcy, courts have ordered the substantive consolidation of bankrupt and non-bankrupt entities. See, e.g., Sampsell v. Imperial Paper \& Color Corp., 313 U.S. 215, 218-19 (1941) (consolidating the assets of a bankrupt corporation with those of its nonbankrupt shareholders); 5 WILLIAM M. COLIIER, COLLIER ON BANKRUPTCY \1100.06[1], at 110035 to $1100-37$, I 1100.06[3], at 1100-49 to 1100-52 (15th ed. 1996).

184. Related companies also may become jointly liable through their own actions. Professor White lists several cases where a parent company became directly liable for its subsidiary's liabilities, such as for defects in the parent's representation of a subsidiary's products or where the parent owned and supplied defective machinery for use by its subsidiary. See White, supra note 10, at $1400 \&$ n.139. White concludes, however, that "[b]ased upon the available evidence, it is impossible to tell how often a plaintiff can mount a plausible case against the parent" based on this approach. Id. at 1400; see also PHILLIP I. BLUMBERG, LAW OF CORPORATE GROUPS: TORT, CONTRACT, AND OTHER COMMON LAW PROBLEMS IN THE SUBSTANTIVE LAW OF PARENT AND SUBSIDIARY CORPORATIONS § 14 (1987 \& Supp. 1999).

185. Substantive consolidation would not be a meaningful remedy, however, where $F 1$ has so many small shareholders that the burden of consolidating their estates is impractical.

186. See note 183 supra (arguing that shareholders themselves need not be in bankruptcy for substantive consolidation to apply to them). 
Although substantive consolidation is discretionary with the judge, its clearest application would be to judgment proofing. Indeed, there is a "liberal" trend toward using substantive consolidation to prevent harm caused by "the widespread use of interrelated corporate structures."187 Courts balance whether the "consolidation yields benefits offsetting the harm it inflicts on objecting parties,"188 which are traditionally creditors of companies whose assets are being consolidated-in our case, creditors of $F 2$ (and, if applicable, also creditors of F3). ${ }^{189}$ If an objecting creditor proves that it has relied on the separate credit of $F 2$ (or $F 3$ ), a court will order consolidation only if the benefits of consolidation heavily outweigh the harm.190

In cases of judgment proofing, courts should especially favor consolidation in balancing benefits and harms. For example, the court in Eastgroup Properties $v$. Southern Motel Assoc., Ltd. ${ }^{191}$ ordered substantive consolidation of a related-company structure that resembles the generic non-arm's length structure we have been considering. Southern Motel Association ("SMA"), a company which can be viewed as the equivalent of $F 2$ in our hypothetical, owned or leased motel properties.192 It then leased or subleased those properties to Gainesville P-H Properties ("GPH"), the equivalent of F1 in our hypothetical, whose only function was to operate the motel properties. ${ }^{193}$ SMA and GPH were under common ownership.194 Because the structure effectively judgment proofed GPH, its creditors "would not receive anything" absent consolidation. 195 The Eleventh Circuit, over the objection of SMA's creditors, affirmed lower court decisions substantively consoli-

187. In re Murray Indus., Inc., 119 B.R. 820, 828 (Bankr. M.D. Fla. 1990).

188. In re Auto-Train Corp., 810 F.2d 270, 276 (D.C. Cir. 1987); accord Eastgroup Properties, 935 F.2d at 249.

189. See Auto-Train Corp., 810 F.2d at 276 (discussing creditors that object to consolidation). In order to reach this balancing test, the proponent of consolidation must show that there is substantial identity between the entities to be consolidated and that consolidation is necessary to avoid some harm or to realize some benefit. See Eastgroup Properties, 935 F.2d at 249. That should not be difficult in the case of judgment proofing because the unity of interests and ownership between various corporate entities, the existence of parent and intercorporate guarantees, and the fact that, absent consolidation, $F 1$ 's creditors will receive only a small portion of their claims while $F 2$ and its shareholders receive a substantial distribution are factors from which a court may conclude that substantive consolidation is warranted. See id. at 249-50.

190. See Auto-Train, 810 F.2d at 276 (discussing creditors that rely on the separate credit of an entity). But see In re Augie/Restivo Baking Co., 860 F.2d 515, 521 (2d Cir. 1988) (denying consolidation where one creditor would suffer unfairly).

191. 935 F.2d 245 (11th Cir. 1991).

192. See id. at 246.

193. See id.

194. See id. at 247.

195. Id. at 248 . 
dating SMA and GPH, even though "each held itself out to the public and to its creditors as a separate corporation." 196

Even outside of a bankruptcy context, courts sometimes use their inherent equitable powers in appropriate cases to "pierce the corporate veil" of a related-company structure.197 If that occurred, it would impose costs on the parties-F2 and $F 3$ in our example-participating in the judgment proofing. For example, where a parent company acquired a subsidiary, cancelled its liability insurance, and drained the subsidiary of assets in order to thwart the claim of a tort creditor, a court allowed the creditor to claim directly against the parent.198 Professor White observes that "[a]lthough the tests for veil piercing are hardly precise, their factors coincide more or less with the acts a parent would have to take to insulate itself from liability generated by a subsidiary."199

196. Id. The issue of whether the common owners, represented by $F 3$ in our hypothetical, also should be consolidated apparently was not raised by the parties. Nonetheless, shareholders are subject to substantive consolidation. See Sampsell v. Imperial Paper \& Color Corp., 313 U.S. 215, 218 (1941) (consolidating the assets of a corporation with those of its shareholders).

197. Piercing the corporate veil and substantive consolidation are similar to the extent that both allow a corporation's assets to be reached for the satisfaction of a related company's debt. See In re Continental Vending Mach. Corp., 517 F.2d 997, 1000 (2d Cir. 1975) (noting the similarity between piercing the corporate veil and consolidation).

198. See Eastridge Dev. Co. v. Halpert Assocs., 853 F.2d 772, 780 (10th Cir. 1988). Professors Easterbrook and Fischel suggest an economic rationale for piercing the corporate veil in a parent-subsidiary context:

If limited liability is absolute, a parent can form a subsidiary with minimal capitalization for the purpose of engaging in risky activities. If things go well, the parent captures the benefits. If things go poorly, the subsidiary declares bankruptcy, and the parent creates another with the same managers to engage in the same activities. This asymmetry between the benefits and costs, if limited liability were absolute, would create incentives to engage in a socially excessive amount of risky activities.

EASTERBROOK \& FISCHEL, supra note 108, at 57.

199. White, supra note 10, at 1401-02. Those factors include common directors and officers; consolidated financial statements; the parent's financing of the subsidiary, arranging its incorporation, and paying its salaries and other expenses; undercapitalization of the subsidiary; and the subsidiary's acting as the parent's alter ego. See United States v. Jon-T Chems., Inc., 768 F.2d 686, 691-92 (5th Cir. 1985). Some commentators focus on undercapitalization: "The data ... suggests [sic] that although undercapitalization is not a guarantee of plaintiff success [in a veil piercing case], it comes reasonably close." WILLIAM L. CARY \& MELVIN ARON EISENBERG, CASES AND MATERIALS ON CORPORATIONS 199 (7th ed. 1995). Asset stripping which causes undercapitalization appears to be widely accepted as a requisite act justifying veil piercing. See, e.g., Kvassay v. Murray, 808 P.2d 896, 905-06 (Kan. Ct. App. 1991) (piercing the corporate veil for asset stripping). Furthermore, commentators have observed that "[t]he legal doctrine of piercing the veil is so amorphous that it leaves a large area in which courts can impose liability based upon a 'smell' test of faimess." Robert B. Thompson, Unpacking Limited Liability: Direct and Vicarious Liability of Corporate Participants for Torts of the Enterprise, 47 VAND. L. REV. 1, 23 (1994); see also Mark A. Olthoff, Beyond the Form-Should the Corporate Veil Be Pierced?, 64 UMKC L. REV. 311, 318 (1995) (noting that "under certain circumstances, a court may find that the conduct was simply 'unjust' or 'inequitable"' to satisfy the wrongful conduct factor). One such commentator, for example, argues that "most decisions to pierce find their real justification in wrongs committed by the defendant in his or her dealings with the plaintiff or abusive dealings ... with the corporation's 
Corporation law also may restrict judgment proofing. ${ }^{200}$ The traditional duty of a corporation's managers, its board of directors, is to the corporation's shareholders, ${ }^{201}$ suggesting that the board would favor payment of dividends to shareholders at the expense of involuntary creditors. Nonetheless, the directors of an insolvent corporation appear to have a duty to creditors as well,202 and that duty might apply even absent actual insolvency.

assets." Franklin A. Gevurtz, Piercing Piercing: An Attempt to Lift the Veil of Confusion Surrounding the Doctrine of Piercing the Corporate Veil, 76 OR. L. REV. 853, 854 (1997).

200. In addition to the corporate governance restrictions that I will discuss, "[e]very state statutorily restricts the directors' authority to make dividend distributions based on the corporation's financial condition." COX ET AL., supra note $59, \S 20.12$, at 20.31. A typical requirement is that dividends be payable solely out of the company's surplus or net profits. See, e.g., DEL. CODE ANN. tit. 8, § 170(a) (1998). This type of limitation, however, may not restrict judgment proofing against future involuntary creditors. Delaware law defines surplus as the "excess, if any, at any given time, of the net assets of the corporation over the amount so determined [by resolution of its board of directors] to be capital," but future claims are not deducted from net assets. $I d$. $\S 154$. Furthermore, the board can determine that only a part of the consideration received for issuance of stock will be capital. See id. Therefore, prior to incurring claims, a Delaware corporation will be able to pay substantially all of its assets as dividends. See Robert Charles Clark, The Duties of the Corporate Debtor to Its Creditors, 90 HARV. L. REV. 505, 557-58 (1977) (arguing that "it is possible for tort creditors of a corporation to be adversely affected by the weak dividend restraints of ordinary business corporation law. At the time a tort claim arises, the corporation's net worth ... may have fallen so low because of past dividend payments that the tort creditor's claim will not be satisfied to any significant degree" (citations omitted)). Some states require that a "certain ratio of certain assets to current liabilities, or assets to liabilities, such as $11 / 4$ to $1, \ldots$ be left after a distribution of dividends in order to avoid impairment of debt-paying ability and working capital position." COX ET AL., supra note 59, $\$ 20.12$, at 20.31 (citing this as an alternative approach used in California). And the Revised Model Business Corporation Act proposes an "equity insolvency test" under which directors must reasonably expect that known obligations will be satisfied over the period of time that they mature. REVISED MODEL BUS. CORP. ACT $\$ 6.40 \mathrm{cmt} .2(1984)$ (noting that directors may not simply compare current assets to current liabilities). These requirements, however, may not significantly affect judgment proofing because corporations can choose where to incorporate. See COX ET AL, supra note 59, § 3.2, at 3.4 to 3.5 ("In selecting the state of incorporation, the attorney makes a decision ... as to the relevant statutory law .... As such, it may be advisable to shop for the jurisdiction that will best suit the organizers' needs."). A corporation that wishes to judgment proof itself thus could reincorporate (or, if new, incorporate itself) in a state that does not impose these requirements. See id. at 3.7 (observing that "[i]t is not unusual today for a corporation to change its domicile through reincorporation").

201. See Revlon, Inc. v. MacAndrews \& Forbes Holdings, 506 A.2d 173, 179 (Del. 1986) (stating that "directors owe fiduciary duties of care and loyalty to the corporation and its shareholders"). There are certain other limited duties arising out of contract or commercial law, but they are not relevant here because of my focus on involuntary creditors who neither have contractual covenants nor engage in commercial transactions with the company. See generally Steven L. Schwarcz, Rethinking a Corporation's Obligations to Creditors, 17 CARDOZO L. REV. 647 (1996) (arguing that a corporate debtor has a commercial law obligation of good faith to abide by courses of dealing and is bound according to explicit contractual obligations, such as covenants) [hereinafter Rethinking a Corporation's Obligations].

202. See Geyer v. Ingersoll Publications Co., 621 A.2d 784, 790 (Del. Ch. 1992) (stating that directors of insolvent corporations owe fiduciary duties to creditors); see also COX ET AL, supra note $59, \S 10.18$, at 10.61-.63 (discussing the contours of this duty); Rethinking a Corporation's Obligations, supra note 201, at 666-68 \& n.100 (citing cases to support the argument that "creditors [of an insolvent corporation] become the primary residual claimants," and therefore "[t]he fiduciary obligation that directors previously owed only to shareholders as owners of the corporation [should] 
Where a corporation is in the "vicinity of insolvency," the Delaware Chancery Court has held that directors owe an obligation to both creditors and shareholders. ${ }^{203}$ I have argued that directors also should have an obligation to creditors where the company's actions have a reasonable expectation of resulting in insolvency.204 Directors who judgment-proof a corporation by distributing assets to its shareholders therefore may be violating their fiduciary obligation to the company's creditors because inability to pay future debts is a form of insolvency.205 Thus, corporate governance law may limit a company's ability to judgment-proof itself.206

There are, additionally, two tort theories207_lender liability and prima facie tort-under which $F 2$, if it helps to judgment-proof $F 1$, may become directly liable to $F 1$ 's creditors. ${ }^{208}$ Under lender liability law, creditors that breach a duty of good faith or fair dealing may become liable not only for

also extend to creditors, whose rights have been transformed by insolvency into equity-type rights").

203. See Credit Lyonnais Bank Nederland, N.V. v. Pathe Communications Corp., No. Civ.A.12150, 1991 WL 277613, at *34 (Del. Ch. Dec. 30, 1991).

204. See Rethinking a Corporation's Obligations, supra note 201, at 672-78 (arguing that a "contingent insolvency" approach "sets a brighter line than Chancellor Allen's approach [in the Credit Lyonnais case] to determine when directors have loyalty to creditors as well as shareholders, but gives more leeway and discretion to directors when that dual loyalty arises").

205. At least under Delaware corporation law, insolvency includes a company's being "unable to pay its debts as they fall due in the usual course of business." Geyer, 621 A.2d at 789.

206. To the extent that the case-law corporate governance restrictions discussed above are not applied in all jurisdictions, those restrictions may not significantly affect judgment proofing because corporations can choose where to incorporate. Cf. note 200 supra (discussing same in the context of state statutory restrictions on the payment of dividends). That choice will determine "the case law that will govern all corporate questions, including the duties of the corporation's officers and directors." COX ET AL., supra note 59, § 3.2, at 3.4. There are, however, several differences between these case law and statutory restrictions that may make the former more applicable to judgment proofing. The development of the relevant case law is being led by courts in Delaware, the jurisdiction that heavily dominates the incorporation of American businesses. See ROBERT W. HAMILTON, CASES AND MATERIALS ON CORPORATIONS 172-75 (6th ed. 1998) (noting that Delaware is the preferred state of incorporation for publicly held corporations). Delaware is one of the more permissive states for incorporation, see COX ET AL., supra note 59, § 3.2, at 3.6 (observing that the state "has generally been regarded as a permissive haven"), suggesting that restrictions in Delaware are more likely to be adopted in less permissive jurisdictions. Finally, "the Delaware judiciary is highly regarded today" and "decisions [of the Delaware Supreme Court] are often followed by courts in other states." HAMILTON, supra, at 175 (observing that even the Delaware Chancery Court "is the envy of other states").

207. For an analysis of the deterrent value of tort law, see generally Gary T. Schwartz, Reality in the Economic Analysis of Tort Law: Does Tort Law Really Deter?, 42 UCLA L. REV. 377 (1994) (concluding, at 443, that although tort law does not "systematically" deter, it does provide "something significant by way of deterrence"). The possibility of punitive damages in the case of lender liability, see notes 208-213 infra and accompanying text, may provide even greater deterrence.

208. I later explain why lender liability law, which imposes liability on creditors, would give rise to F2's liability to creditors in a judgment proofing transaction. See note 220 infra and accompanying text. 
harm caused to the debtor but also for punitive damages. ${ }^{209}$ For example, in K.M.C. Co. v. Irving Trust Co.,210 a bank which refused to lend $\$ 800,000$ to a borrower was held liable, even though the bank had no contractual obligation to lend.211 The court held that the bank's sudden refusal to continue lending to the borrower, which had no other source of funds, was not in good faith given the bank's past practice of lending money upon request; the bank at least should have given the borrower notice and a reasonable opportunity to arrange for alternate financing.212 The court upheld a jury award of $\$ 7.5$ million-the amount of K.M.C.'s damages-against the bank, notwithstanding the award's being almost ten times the size of the refused loan.213

The same tort theory that underlies lender liability law-that creditors may be violating a duty of fair dealing they owe to their debtor ${ }^{214}$ - could be applied to judgment proofing. The duty of fair dealing that a lender owes to its debtor neither arises out of contract215 nor rises to a fiduciary level.216 Rather, the duty is based on an implied obligation to exercise good faith in commercial transactions, inspired by the good faith duty under the Uniform

209. See Frances E. Freund, Susan D. Gresham, Robert D. Rowe \& N. Sue Van Sant Palmer, Special Project, Lender Liability: A Survey of Common-Law Theories, 42 VAND. L. REV. 855, 85758 (1989) (noting the "multimillion dollar punitive damages available under a tort theory"); see also, e.g., First Nat'l Bank in Libby v. Twombly, 689 P.2d 1226, 1230 (Mont. 1984) (imposing punitive damages in a lender liability case).

210. 757 F.2d 752 (6th Cir. 1986).

211. The bank provided an uncommitted line of credit for up to $\$ 3.5$ million. The particular loan in question, however, was only $\$ 800,000$. See id. at 754 .

212. See id. at 761-63. The court also appeared concerned that a personality dispute between a representative of the bank and an officer of the borrower led to the refusal to lend. See id. at 761 .

213. See id. at 766.

214. See Freund et al., supra note 209, at 883-84 (discussing tort actions against lenders for bad faith); Wemer F. Ebke \& James R. Griffin, Lender Liability to Debtors: Toward a Conceptual Framework, 40 Sw. L.J. 775, 795-98 (1986) (discussing the duty of good faith and fair dealing that underlies lender liability cases). Lender liability cases sometimes are based on other theories, including breach of contract, fraud, duress, interference, and negligence. See Freund et al., supra note 209, at 855-85 (discussing these theories).

215. The lender liability duty of good faith is "imposed by law." See Freund et al., supra note 209, at 884-85. It also may be imposed by contract, but a contract is not necessary for the duty to arise. See id. Indeed, Easterbrook and Fischel argue that courts are more willing to pierce the corporate veil and impose liability in tort cases than in contract cases because contract creditors are compensated for the increased credit risk while tort creditors are not. See EASTERBROOK \& FISCHEL, supra note 108, at 58. But see Robert B. Thompson, Piercing the Corporate Veil: An Empirical Study, 76 CORNELL L. REV, 1036, 1058 (1991) (discussing empirical data showing that courts have pierced the veil more often in contract than tort cases).

216. A debtor-creditor relationship is not generally fiduciary. See, e.g., In re Ludwig Honold Mfg. Co., 46 B.R. 125, 128 (Bankr. E.D. Pa. 1985) (observing that creditors generally have no fiduciary obligations to debtors); In re Teltronics Servs., Inc., 29 B.R. 139, 169 (Bankr. E.D.N.Y. 1983), aff'd, 762 F.2d 185 (2d Cir. 1985) (same). But see A. Gay Jenson Farms Co. v. Cargill, Inc., 309 N.W.2d 285, 293 (Minn. 1981) (imposing lender liability based on the special relationship between the lender and the borrower). 
Commercial Code.217 Thus, the parties need not be in a contractual or fiduciary relationship for lender liability to be imposed.

By helping to make $F 1$ judgment proof in order to gain an advantage at the expense of $F 1$ 's creditors, $F 2$ may well be violating an implied obligation of good faith to those creditors. 218 Courts are not reluctant to extend lender liability to further their own sense of justice.219 Thus, $F 2$ could be held liable to $F 1$ 's creditors on a lender liability theory. 220

The extension of lender liability to judgment proofing also makes economic sense. It has been argued that the common law rationale for piercing the corporate veil

may be understood, at least roughly, as attempts to balance the benefits of limited liability against its costs. Courts are more likely to allow creditors to reach the assets of shareholders where limited liability provides minimal gains from improved liquidity and diversification [of investor risk in the corporation], while creating a high probability that a firm will engage in a socially excessive level of risk taking. ${ }^{221}$

This same rationale is applicable to arm's length judgment proofing transactions that are not subject to veil piercing. Judgment proofing provides minimal gains from improved liquidity and diversification but creates a high probability that $F 1$ will engage in a socially excessive level of risk taking.

217. The Uniform Commercial Code, or U.C.C., provides that "[e]very contract or duty within this Act imposes an obligation of good faith in its performance or enforcement." U.C.C. $\S 1$ 203 (1989). Although the U.C.C. does not technically apply either to debtor-creditor or judgment proofing transactions, some courts have imputed a duty of good faith in all commercial transactions, even to those outside the purview of the U.C.C. See, e.g., Greenberg v. Service Bus. Forms Indus., Inc., 882 F.2d 1538, 1540-42 (10th Cir. 1989) (per curiam); K.M.C. Co. v. Irving Trust Co., 757 F.2d 752, 759 (6th Cir. 1985) (comparing U.C.C. good faith principles to a non-U.C.C. situation and inferring a good faith duty as the basis for lender liability); Noonan v. First Bank Butte, 740 P. 2d 631, 634 (Mont. 1987) (applying § 1-203 to a debtor-creditor context); First Nat'l Bank in Libby v. Twombly, 689 P.2d 1226, 1230 (Mont. 1984) (finding that bank breached its obligation to act in good faith); see also Werner F. Ebke \& James R. Griffin, Good Faith and Fair Dealing in Commercial Lending Transactions: From Covenant to Duty and Beyond, 49 OHI ST. L.J. 1237, 1241 (1989) (observing that even where the Uniform Commercial Code does not apply directly, courts have had little theoretical difficulty imposing upon lenders an obligation of good faith and fair dealing).

218. If $F 2$ demands extraordinary compensation to offset the risk of having a judgment proof lessee, it could not even argue that its sale-leaseback transaction with $F 1$ has independent business justification.

219. See William M. Burke, Tom Thomas \& William D. Warren, Emerging Theories of Bank Liability, in BANKS AND THEIR BORROWERS: NEW OPPORTUNITIES IN FINANCIAL SERVICES 403, 458 (1984) (observing that the use of fair dealing to impose lender liability is a "loose cannon [which] may be used by courts to further their views of justice").

220. Although different parties are involved in lender liability than in judgment proofing, that distinction appears formalistic. In both situations, the parties may be seen to be dealing unfairly in order to take advantage of third parties - to recover their claims in the case of lender liability, and to obtain compensation in the case of judgment proofing.

221. EASTERBROOK \& FISCHEL, supra note 108 , at 55 . 
Accordingly, if $F 2$ helps to judgment-proof $F 1$, courts should be more likely to allow $F 1$ 's creditors to reach $F 2$ 's assets.

A court that wishes to punish the parties involved in a judgment proofing also might resort to the shadowy doctrine of prima facie tort.222 Described by some courts as a "misty shroud," 223 the doctrine has been adopted in "the overwhelming majority" of states that have considered it.224 The doctrine provides that "[o]ne who intentionally causes injury to another is subject to liability to the other for that injury, if his conduct is generally culpable and not justifiable under the circumstances. This liability may be imposed although the actor's conduct does not come within a traditional category of tort liability."225 The element of intent to injure is satisfied in most jurisdictions when the defendant "knows or believes that the consequence is certain, or substantially certain, to result from his act," irrespective of whether the defendant wishes to cause injury.226 Furthermore, the element of lack of justification appears to focus less on whether there is a valid business reason, such as compensation or shareholder benefit, and more on whether the conduct is "in accord with community standards of right conduct."227 Hence, F2 or F3 might be held liable to $F 1$ 's creditors on the theory that they knew or believed that those creditors would be substantially certain not to recover their claims from a judgment proof $F 1$, and that $F 2$ and $F 3$ 's conduct-aiding and abetting a judgment proofing -is not in accord with community standards of right conduct.

Finally, the officers and directors of $F 1, F 2$, and $F 3$ (as well as $F 2$ and $F 3$ in their corporate capacities) might be subject to RICO, which would allow injured persons ( $F 1$ 's creditors) to recover treble damages and the costs of their lawsuits 228 and also would impose criminal liability.229

RICO imposes liability on persons associated with an "enterprise" engaged in interstate commerce who conduct the affairs of that enterprise

222. See Kenneth J. Vandevelde, The Modern Prima Facie Tort Doctrine, 79 KY. L.J. 519, 555 (1991) (observing that "[p]rima facie tort, in the final analysis, merely embodies in doctrinal form the fluidity of tort law").

223. Id. at $519 \&$ n.1.

224. Id. at 525 .

225. RESTATEMENT (SECOND) OF TORTS $\$ 870$ (1979).

226. Id. at cmt. b; see also Vandevelde, supra note 222, at 529 (stating that the element of intent requires "only that the defendant have acted with substantial certainty that injury would occur"). However, New York, the jurisdiction with the most experience litigating prima facie tort, restricts its application to situations in which the defendant is motivated "solely by malice." Id. at $540 \&$ n. 128 (citing New York cases to that effect).

227. RESTATEMENT (SECOND) OF TORTS $\$ 870, \mathrm{cmt}$. e.

228. 18 U.S.C. $\$ 1964$ (c) (1994).

229. 18 U.S.C. $\S 1963$ (1994). RICO itself may not be applied without an underlying predicate criminal activity, for which there would be separate criminal liability. I later discuss, however, the practical reasons why RICO liability may be a much greater deterrent to judgment proofing. See notes 235-248 infra and accompanying text. 
"through a pattern of racketeering activity."230 The parties involved in judgment proofing $F 1$ arguably would constitute an "enterprise," which is broadly defined as "any individual, partnership, corporation, association, or other legal entity, and any union or group of individuals associated in fact although not a legal entity." 231 For RICO to apply, the enterprise also must conduct its affairs through a pattern of racketeering activity. The predicate criminal acts that establish racketeering activity are specifically set forth in RICO.232 In the context of judgment proofing, these acts arguably could include bankruptcy fraud,233 financial institution fraud,234 or perhaps even mail fraud or wire fraud. 235

Before examining these predicate acts, I will put them into perspective. RICO may not be applied to judgment proofing without a predicate criminal act, so a judgment proofing that causes such an act would be criminal already. What, then, does RICO add to the crime? There are three answers. First, the types of predicate acts that result from judgment proofing in many ways resemble ordinary commercial transactions, and it may be difficult to prove criminal intent. Prosecutors therefore may be reluctant to bring criminal prosecution. Nonetheless, "[e]ven if it is more likely than not that the activity is not criminal, or that no prosecutor would ever bring a case ..., RICO might become relevant, as it has in most of the civil RICO suits that have been brought, because private plaintiffs [such as injured creditors] are likely to take a more aggressive view of the content of the criminal law than prosecutors will."236 Second, in a civil RICO case, plaintiffs need only prove

230. 18 U.S.C. $\$ 1962$ (c) (1994). For an excellent discussion of the origins and history of RICO, see Gerard E. Lynch, A Conceptual, Practical, and Political Guide to RICO Reform, 43 VAND. L. REV. 769, 770-76 (1990).

231. 18 U.S.C. $\$ 1961$ (4) (1994). The definition is so broad that it might even include shareholders of an undercapitalized $F 1$ who guaranty rentals on leased assets.

232. Those predicate acts are specified in 18 U.S.C. $\S 1961$ (1) (1994), the definition of "racketeering activity." Bad acts that are not so specified do not qualify. See Lewis v. Sporck, 612 F. Supp. 1316, 1325 (N.D. Cal. 1985).

233. See 18 U.S.C. $\$ 1961$ (1)(D) (1994), which provides that "any offense involving fraud connected with a case under title 11 [the Bankruptcy Code] ... punishable under any law of the United States" is a predicate act under RICO. Although it is doubtful whether a fraudulent conveyance that is merely voidable under 11 U.S.C. $\S 548$ would constitute such a predicate act, it seems clear that a bankruptcy fraud under 18 U.S.C. $\S 152$ would constitute a predicate act, because such frauds are punishable by up to five years imprisonment; see DOUGLAS E. ABRAMS, THE LAW OF CIVIL RICO $\S 5.3 .4$, at 283-85 (1991 \& 1998 Supp.) (observing that "[ $t]$ he bankruptcy fraud predicate [of RICO] would include at least violations of 18 U.S.C. $\S 152$ ").

234. See 18 U.S.C. $\$ 1961$ (1)(B) (1994), which provides that financial institution fraud is a predicate act under RICO to the extent it is indictable under 18 U.S.C. $\S 1344$.

235. 18 U.S.C. $\$ 1961$ (1)(B) (1994) provides that mail fraud and wire fraud are predicate acts under RICO to the extent those instances of fraud are indictable under 18 U.S.C. $\$ 1341$ or $\S 1343$, respectively.

236. Letter from Gerard E. Lynch, Professor, Columbia Law School, to the author (Dec. 21, 1998) (on file with author). Professor Lynch explains that "[p]rosecutors will shy away from bringing [a contract fraud case] because it 'looks like' a civil rather than criminal matter, and be- 
the occurrence of predicate acts "by the usual preponderance of the evidence [civil] standard."237 Finally, the enterprise liability approach of RICO may extend liability to parties who would not be subject to liability for the predicate act under non-RICO law.

There should be little problem finding one or more criminal predicate acts in a judgment proofing transaction. Bankruptcy fraud, for example, applies to "an agent or officer of any ... corporation [that], in contemplation of a case under title 11 by or against ... any ... corporation, or with intent to defeat the provisions of title 11 , knowingly and fraudulently transfers or conceals any of ... the property of such ... corporation." 238 Officers and directors of F1 may be engaging in such fraud even if, at the time of the judgment proofing, bankruptcy is only a distantly contemplated possibility. 239 From that predicate act, RICO would impose enterprise liability on $F 2$ and $F 3$, and their officers and directors, to the extent they participate in the fraud. 240

Judgment proofing also might constitute financial institution fraud, which applies whenever a person "knowingly executes, or attempts to execute, a scheme or artifice ... to defraud a financial institution."241 The term

cause the proof of intention is difficult given the criminal burden of proof. But private civil plaintiffs find it easy to bring the civil suit, and to make the allegation in good faith that the [party breaching the contract] had criminal intent." Id. at 2. Thus, "RICO creates an opportunity for claims of fraud or criminality to be made in situations where prosecutors would fear to tread...." Id. at 3 .

237. ABRAMS, supra note $233, \S 5.3$, at 265 .

238. 18 U.S.C. $\$ 152(7)$ (1994). For a recent overview of bankruptcy fraud, see Symposium, Bankruptcy Fraud, 6 AM. BANKR. INST. L. REV. 271 (1998). As part of that symposium, an Assistant United States Trustee observes that "prosecutions [for bankruptcy fraud] have increased across the country for a couple of reasons." Roundtable Discussion Comments of Sandra Rasnak, id. at 277 (giving as reasons the better working relationships between bankruptcy court officers and federal criminal investigative agencies and Attorney General Janet Reno's priority focus on bankruptcy fraud).

239. See United States v. West, 22 F.3d 586, 589-90 (5th Cir. 1994). The one year limitation of bankruptcy fraudulent conveyance law under 11 U.S.C. $\S 548$ is not applicable to 18 U.S.C. $\S$ 152, which applies to "transfers of property occurring more than one year prior to the filing of a petition in bankruptcy" if its statutory requirements are otherwise met. West, 22 F.3d at 590.

240. See notes 230-231 supra and accompanying text (explaining enterprise liability). Alternatively, those parties would be liable under aiding and abetting and conspiracy theories. See, e.g., 18 U.S.C. $\$ 1962$ (d) (1994) (making it "unlawful for any person to conspire to violate any of the provisions of' RICO); United States. v. Pungitore, 910 F.2d 1084 (3d Cir. 1990) (upholding RICO conviction based, inter alia, on defendant's predicate offense of conspiracy).

241. 18 U.S.C. $\$ 1344$ (1994). Courts have interpreted "financial institution" to mean one that is federally chartered or insured. See, e.g., United States v. Jacobs, 117 F.3d 82, 93 (2d Cir. 1997) ("Consequently, "a conviction under the "scheme to defraud" clause of the bank fraud statute requires ... a pattern or course of conduct designed to deceive a federally chartered or insured financial institution into releasing property, with the intent to victimize the institution by exposing it to actual or potential loss." (quoting United States v. Stavroulakis, 952 F.2d 686, 694 (2d Cir. 1992))). 
"scheme to defraud" is broadly construed to include any plan or pattern"242 that departs from "fundamental honesty, moral uprightness, or fair play and candid dealings."243 Furthermore, courts have upheld financial institution fraud as a predicate act for application of RICO even where the financial institution in question was not the actual or intended victim of the scheme to defraud but merely was exposed to risk of loss on its claim for repayment.244 To the extent judgment proofing exposes a financial institution creditor of $F 1$ to a risk of loss on its claim for repayment, financial institution fraud would appear to be a predicate crime for the application of RICO.245

Because RICO already has been applied in a wide range of commercial cases, ${ }^{246}$ creditors injured in a judgment proofing are likely to claim a RICO violation.247 Despite protests that RICO's application has exceeded the original statutory intent, the Supreme Court has rejected attempts to narrow its scope, ${ }^{248}$ noting that RICO provides that its provisions are to be "liberally

242. See United States v. Goldblatt, 813 F.2d 619, 624 (3d Cir. 1987) (defining the term "scheme" to include any plan or pattern).

243. See United States v. Ragosta, 970 F.2d 1085, 1090 (2d Cir. 1992) (affirming that a "scheme to defraud" may include any scheme that departs from "fundamental honesty, moral uprightness, or fair play and candid dealings in the general life of the community" (quoting Goldblatt, 813 F.2d at 624)); see also United States v. Norton, 909 F. Supp. 567, 568 (N.D. Ill. 1995), aff', 108 F.3d 133 (7th Cir. 1997) (same). Thus, evidence of pledging the same item of collateral for separate loans is sufficient to establish a scheme to defraud. See United States v. Sheahan, 31 F.3d 595, 601 (8th Cir. 1994) (holding that double-pledging "at least one item of collateral" was evidence of violating "fundamental honesty, moral uprightness, or fair play and candid dealings").

244. See Stiller v. Sumter Bank \& Trust Co., 860 F. Supp. 835, 839 (M.D. Ga. 1994) ("As long as the bank is exposed to the risk of loss by some scheme or artifice, the statute has been violated." (citing United States v. Briggs, 965 F.2d 10, 12 (5th Cir. 1992))).

245. Although not as explicitly applicable to judgment proofing, mail and wire fraud also might constitute predicate acts in appropriate cases for the application of RICO. See Lynch, supra note 230 , at 795 ("An aggrieved party can describe most kinds of commercial dispute as some species of fraud, and, therefore, given the ubiquity of the mails and interstate wire communications, as mail or wire fraud.").

246. See, e.g., United States v. Porcelli, 865 F.2d 1352 (2d Cir. 1989) (tax evasion); United States v. Regan, 726 F. Supp. 447 (S.D.N.Y. 1989), aff'd in part, vacated in part on other grounds, 937 F.2d 823 (2d Cir. 1991) (securities fraud); Northeast Women's Ctr., Inc. v. McMonagle, 868 F.2d 1342 (3d Cir. 1989) (abortion protestors); cf. Bruns v. Ledbetter, 583 F. Supp. 1050, 1055 (S.D. Cal. 1984) (observing that a broad reading of RICO "would literally make a federal case out of nearly every instance of business fraud"); Lynch, supra note 230, at 794 (noting that allegations of business or securities fraud, regarded by many as "'garden variety commercial disputes,' comprise nearly three-quarters of all reported RICO cases"); E.F. Mannino, Lender Liability and Banking Litigation $\$ 4.02$ (1989) (citing a variety of civil RICO actions involving financial institutions).

247. Indeed Edward Mannino, speaking at a law school symposium on RICO, observed that "it may now be malpractice not to include a RICO count in a civil complaint in commercial litigation." Anne B. Poulin, RICO: Something for Everyone, 35 VILL. L. REV. 853, 857 (1990); see also Absence of RICO Claim in Securities Suits Termed "Malpractice" by Attorney, 16 Secs. Reg. \& L. Rep. (BNA) No. 18, at 754 (May 4, 1984) (reporting the similar remarks of attorney Jerold S. Solovy).

248. See Sedima, S.P.R.L. v. Imrex Co., 473 U.S. 479, 497 (1985) ("RICO is to be read broadly."); Poulin, supra note 247, at 860 (noting that Congress has steadfastly refused to significantly narrow RICO's scope). 
construed to effectuate its remedial purposes."249 Irrespective of whether a RICO claim ultimately will be successful,250 its "mobster" stigma and the fact that the claim may be asserted against individual officers and directors is likely to have a significant deterrent effect.

Judgment proofing therefore is regulated by laws that not only restrict a company's ability to judgment-proof itself but also may impose costs on the parties participating in the judgment proofing transaction.251 Those costs may even include punitive damages, treble damages, and criminal liability. Moreover, where existing legal doctrines do not clearly cover judgment proofing, it is but a short step conceptually to apply those doctrines to it. ${ }^{252}$ There still remains an issue, however, of whether the costs of judgment proofing will be significantly discounted, given the uncertainty of their infliction. I next show that, at least in an arm's length context, they will not.

Irrespective of the ex ante probability that costs will be incurred, the consequences could be devastating. Just how the parties view these potential costs will be somewhat different in arm's length and non-arm's length transactions. As I have already shown, $F 2$ will be risk averse in an arm's length transaction 253 and therefore will be more likely to view the costs as reasonably serious possibilities that would, in turn, be irrational to discount: "[i]n evaluating risks, risk-averse persons tend to assign too much weight to events that have a low probability of occurrence, when the consequences of

249. Organized Crime Control Act of 1970, Pub. L. No. 91-452, § 904(a), 84 Stat. 947.

250. For example, the application of RICO to a parent-subsidiary structure might be questioned because courts are split as to whether a parent and its wholly owned subsidiary are capable of conspiring with each other. See ABRAMS, supra note $233, \S 4.8$, at 250-51.

251. Laws may impose costs in other ways, such as by setting minimum insurance requirements. For example, Professor White argues that "[m]easured by the number of potential claims, workers' compensation may be the single largest barrier to judgment proofing." White, supra note 10 , at 1409 . Workers' compensation, however, is only a barrier to a company's ability to judgment proof itself against claims of its employees who are injured in the course of their employment.

252. The history of the common law is full of examples of courts extending existing legal doctrines to remedy injustices: "[T]he common law is not static; its life and heart is its dynamism-its ability to keep pace with the world while constantly searching for just and fair solutions to pressing societal problems." Harrison v. Montgomery County Bd. of Educ., 456 A.2d 894, 903 (Md. 1983). Thus, in Schmoll v. Acands, Inc., 703 F. Supp. 868 (D. Or. 1988), aff'd, 977 F.2d 499 (9th Cir. 1992), a corporation being subjected to massive asbestos-related personal injury lawsuits restructured itself through "an elaborate, apparently unique transfer of corporate assets," $i d$. at 872, that was "designed to [enable it to] escape liability," id. at 873 . Even though "the corporate restructuring [met] the technical formalities of corporate form," the court held the transferee of the assets liable for the transferring corporation's claims. Id. at 874 . The court's rationale was that the transfer "was designed with the improper purpose of escaping asbestos-related liabilities," id. at 874 , and "[u]pholding the integrity of such transactions would unjustly elevate form over substance," $i d$. at 875 . (The court also could have voided the transfer under fraudulent conveyance law, but apparently the plaintiff preferred to impose successor liability on the transferee. See id. at 874 n.11).

253. See note 138 supra and accompanying text (arguing that $F 2$ will be risk averse because it is engaging in a task for gain, in the form of compensation). 
such events are extremely adverse."254 F2 therefore would want to avoid judgment proofing in order to avoid these costs. 255

However, the parties are more likely to discount these costs in a nonarm's length transaction. We are most concerned with the perception of $F 3$, the common owner of $F 1$ and $F 2$. In a non-arm's length transaction, $F 3$ cannot know ex ante whether the costs of judgment proofing will exceed its benefits. $F 3$ also may be risk prone. Thus, $F 3$ is more likely to discount these costs as unrealistic.

These ambiguities make it difficult for economic analysis alone to predict the extent to which non-arm's length judgment proofing will occur or to answer the broader question of whether non-arm's length judgment proofing is adequately regulated by law. Nevertheless, by examining empirical evidence, I next argue that the rate of non-arm's length judgment proofing is unlikely to increase in the future.

\section{E. Is Non-Arm's Length Judgment Proofing Adequately Regulated by Law?}

Non-arm's length judgment proofing would occur where its benefit, $\Delta$, exceeds its costs to related companies $F 1, F 2$, and $F 3$. Although economic analysis alone cannot predict the precise relationship between $\Delta$ and those costs, empirical evidence reveals that the relationship will be stable over time.

Professor White has compiled fifteen years of empirical data on American companies that may be relevant.256 He shows that the ratio of assets to liabilities has remained constant, from which he concludes that companies remain adequately capitalized.257 $\mathrm{He}$ also shows that the amount of secured debt as a percentage of assets appears to be declining, suggesting that companies are not increasing their use of secured debt strategies for judgment proofing. ${ }^{258}$ Finally, he shows that although buying liability insurance is inconsistent with judgment proofing, the data indicate no significant diminution in the level of liability insurance outstanding. 259

254. See Alexander, supra note 107 , at 531 .

255. Cf. Christina L. Kunz, Frontispiece on Good Faith: A Functional Approach Within the UCC, 16 WM. MITCHELL L. REV. 1105,1110 (1990) (arguing that some uncertainty in the law can increase socially desirable behavior by motivating parties to act within the range of clearly acceptable behavior).

256. See White, supra note 10, at 1369-93. His data cover the period 1981-1995. See id. at 1371 n.42.

257. See id. at $1374-80$.

258. See id. at 1371-74. Recall that LoPucki concludes that secured debt strategies are "so deep-rooted in culture that they are virtually impossible to change." Death of Liability, supra note 1 , at 4.

259. See White, supra note 10 , at $1380-88$. 
White's data do not, however, reveal the relative relationship between $\Delta$ and the cost of judgment proofing because they do not show whether judgment proofing exists at all and, if so, at what level.260 Nonetheless, the data do indicate that the ratio of $\Delta$ to such cost is not increasing-for if that ratio were increasing, the level of judgment proofing similarly would be expected to rise. Therefore, if the current level of judgment proofing is socially acceptable, Professor White's data predict that judgment proofing will continue at a socially acceptable level and will not, as claimed, rise to a level that undermines the system by which money judgments are enforced. 261

White cautions that his "data do not foreclose the possibility that Professor LoPucki's claims [that American businesses are rendering themselves judgment proof] will turn out to be correct in the future."262 But the following analysis suggests that White's caution goes too far.

Non-arm's length judgment proofing has been around for centuries.263 Therefore there is little reason to believe-and certainly none has been ad-

260. By "relative relationship," I mean which is greater: $\Delta$ or the cost of judgment proofing.

261. White's data are not, however, conclusive on this point. His analysis of corporate secured debt as a percentage of assets does not take into account what may be the most common form of secured debt-non-recourse debt-which does not generally appear on a company balance sheet and therefore would not be included in the data examined by Professor White. See Easy Case, supra note 15, at 462-65. One therefore cannot know from such data whether overall secured debt, as a percentage of assets, is increasing or decreasing. His analysis of corporate assets-to-liabilities ignores that companies, which generally prefer lower asset-to-liability ratios, could manipulate that ratio. For example, a company that incurs non-recourse as opposed to ordinary debt would not affect that ratio because non-recourse debt does not generally appear on a company balance sheet. See, e.g., SECURTIZATION, supra note 21, at 2 (showing the impact of non-recourse debt on a company's financial ratios and explaining how a company could lower its asset-to-liability ratio by using the proceeds of non-recourse debt to repay liabilities). Finally, White's analysis of changes in outstanding liability insurance between 1982 and 1995 does not necessarily overcome the response that even judgment proof companies will buy liability insurance so long as the cost of insurance is less than the cost of bankruptcy. See Death of Liability, supra note 1, at 76.

262. White, supra note 10 , at 1394.

263. See id. at 1364 ("Taking secret security, making fraudulent conveyances, operating with insufficient capital, and distributing one's assets to shareholders in preference to creditors have been practiced for hundreds of years ....”). Non-arm's length judgment proofing has even been satirized by Gilbert and Sullivan in the last century:

Some seven men form an Association,

(If possible, all Peers and Baronets)

They start off with a public declaration

To what extent they mean to pay their debts.

That's call'd their Capital: if they are wary

They will not quote it at a sum immense.

The figure's immaterial-it may vary

From eighteen million down to eighteen pence.

I should put it rather low;

The good sense of doing so

Will be evident at once to any debtor.

....

If you succeed, your profits are stupendous-

And if you fail, pop goes your eighteen pence. 
vanced to suggest-that non-arm's length judgment proofing will be more innovative in the future than has been attempted in the past.264 Both the parent-subsidiary ownership strategy as well as the more generic non-arm's length structure referred to in this article are merely examples of the ancient technique of "distributing one's assets to shareholders in preference to creditors." 265 These structures have been well-known and widely used for decades, and there is nothing to hint that business innovations or new technologies are likely to make them more prevalent. ${ }^{266}$ Even the possibility that mass tort claims will increase in the future would not necessarily increase $\Delta$, because $\Delta$ is limited by the value of $F I$ 's interest in its assets. 267 To the contrary, an increase in $F 1$ 's tort claims actually could deter judgment proofing because the liability of $F 2$ and $F 3$ is not limited by the amount of $F 1$ 's assets. 268 Thus White's empirical data at least should be persuasive evidence that the level of non-arm's length judgment proofing will not increase. ${ }^{269}$ If

$\cdots$

If you come to grief, and creditors are craving

....

You merely file a Winding-Up Petition,

And start another Company at once!

W.S. GILBERT, UTOPIA LMITED; OR, THE FLOWERS OF PROGRESS, Act I, Finale, No. 11c (1893) (satirizing judgment proofing by undercapitalization).

264. Professor LoPucki claims, however, that computerization will make the logistics of judgment proofing easier and cheaper by helping to keep track of assets transferred among members of a corporate group and lowering the transaction costs of maintaining elaborate corporate structures. In Judgment Proofing: A Rejoinder, 52 STAN. L. REV. 77 (1999), I show that claim is irrelevant. Non-arm's length strategies, which are merely examples of the ancient strategy of distributing one's assets to shareholders in preference to creditors, will not be changed by computerization. Computerization also cannot reduce legal liabilities, which provide the real deterrent to judgment proofing. In any event, because I assign no costs to the types of logistical factors that computerization can facilitate, my analysis already implicitly assumes computerization.

265. White, supra note 10, at 1364. The use of SPVs in securitization transactions also has been common for decades. See SECURITIZATION, supra note 21, at 3-4 (examining the history of securitization).

266. Indeed, it is the age-old sale-leaseback transaction that transforms $F 1$ 's assets into cash (which $F I$ then pays as dividends to its shareholders), yet there does not appear to be any obvious pattern of companies engaging in such transactions for judgment proofing.

267. See note 91 supra and accompanying text (explaining that once F1's liabilities are equal to its assets, an increase in liabilities would not increase $\Delta$ ).

268. See notes 162-252 supra and accompanying text (explaining that $F 2$ and $F 3$ may become subject to all of $F 1$ 's liabilities, and that those liabilities can be avoided simply by adequately capitalizing $F I$ ).

269. Whether existing regulation is the most efficient is beyond the scope of this article. Nonetheless, I offer the following observations. The objective of regulating judgment proofing should be to internalize its costs to the parties participating in it. Those parties are then more likely to take the socially optimal level of care, and judgment proofing is less likely to impose health-care and welfare costs. See A.C. PIGOU, THE ECONOMICS OF WELFARE 172 (4th ed. 1932) (arguing that the failure of companies to internalize their costs will cause a divergence between the values of the marginal private net product entailed with the companies' activities and the social net product); STEVEN SHAVELL, ECONOMIC ANALYSIS OF ACCIDENT LAW 22-23 (1987) (arguing that the socially optimal behavior of injurers can be determined by finding the level of care that minimizes 
that level is presently socially acceptable, it is likely to remain so in the future.

\section{CONCLUSION}

The claim that innovative business transactions will kill liability is simply wrong. Liability is not dying, nor is the system by which money judgments are enforced beginning to fail. Arguments to the contrary blur the distinction between structuring business transactions and the unrelated step of paying dividends and ignore that, in arm's length transactions, any transferred value will be replaced by an equivalent value or better. Those arguments therefore present a world other than the ordinary commercial world in which we live.

Judgment proofing can best be analyzed by separating arm's length transactions from non-arm's length transactions based on the different motivations, perspectives, and costs inherent in each. In an arm's length transaction, each company seeks independent gain; whereas in a non-arm's length

total accident costs incurred each time injurers engage in their activities and then raising the activity level as long as utility outweighs injury costs). There is, however, an inherent problem with the traditional ways of intemalizing judgment proofing costs: Even if $F$ 's liability is extended to $F 2$ and $F 3$, their assets may be insufficient to pay all the costs. Because costs cannot be quantified ex ante, it is impossible to adequately capitalize any given company to ensure that its costs will be internalized. Government could, of course, require highly conservative levels of capitalization, but that would make U.S. companies uncompetitive in a global marketplace. In this context, it is interesting to compare the experience with bank capital requirements. In 1985, the U.S. Federal Reserve Board imposed minimum capital requirements on U.S. banks. See Camille M. Caesar, CapitalBased Regulation and U.S. Banking Reform, 101 YALE L.J. 1525, 1534-35 (1992). The main objectives were to strengthen the financial position of U.S. banks, to enhance the security of bank liabilities, and to shield the U.S. deposit insurance safety net from excessive risk taking. See id. at 1530. Regulators were concerned, however, that the cost of complying with these requirements would create a competitive disadvantage for U.S. banks as against foreign banks. See id. at 1539 . In response, U.S. regulators lobbied central banks in other countries to adopt uniform international minimum capital requirements, culminating in the adoption in 1988 of the Basle Accord which imposes a minimum capital/risk-weighted asset ratio of $8 \%$ for international banks. See Hal S. Scott, The Competitive Implications of the Basle Capital Accord, 39 ST. LOUS U. L.J. 885, 885 (1995). There is, however, another solution that, absent global regulation, has been useful in other contexts. By pooling the potential liabilities of many companies, it is statistically more feasible to match the assets to liabilities. The traditional way of accomplishing this is liability insurance, which could be made mandatory. But mandatory insurance may not be feasible in industries where large liability claims are likely and therefore statistical risk is harder to manage. There, the govemment could require companies to collectively internalize their liabilities by creating a mandatory fund, paid for by companies in each industry, to compensate involuntary creditors. There is significant precedent for doing this to protect employee pensions and also to protect against environmental and nuclear liability. See, e.g., Employee Retirement Income Security Act of 1974 (ERISA), 29 U.S.C. $\S 1082$ (1999); Price-Anderson Amendment Act of 1988, 42 U.S.C. $\S 2210$ (1994 \& Supp. 1999). For a descriptive economic analysis of these and similar alternatives, see EASTERBROOK \& FISCHEL, supra note 108, at 60-62. 
transaction, judgment proofing only needs to benefit the controlling company.

Arm's length business transactions, no matter how innovative, are unlikely to be used for judgment proofing. A sale-leaseback, the threshold transaction that gives rise to arm's length judgment proofing, is taxable. Even if a company $(F 1)$ seeking to judgment-proof itself is willing to pay those taxes and to compensate an unrelated company $(F 2)$ to buy its assets and lease them back, the companies are unlikely to agree on compensation because inherent costs are apt to make judgment proofing more expensive for $F 2$ than is valuable for $F 1$. As well as being an economically dubious strategy, arm's length judgment proofing introduces risks of adverse publicity, job loss, and personal civil and criminal liability, which managers of $F 2$ will seek to avoid.

Social psychology strengthens this economic analysis. Research has shown that people's risk attitudes toward a particular task depend on whether they perceive a potential gain or loss from engaging in the task. Tasks for which a person perceives potential gains typically produce risk-averse behavior; tasks for which a person perceives potential losses yield risk-seeking behavior. Because arm's length transactions are voluntary, $F 2$ presumably would enter into arm's length judgment proofing transactions, if at all, solely for gain. $F 2$ therefore would be risk averse in negotiating the terms of the transaction, increasing the difficulty of agreeing on a mutually acceptable level of compensation. Also, because the costs of judgment proofing could be devastating, $F 2$ is unlikely to discount these costs, even given the uncertainty of their infliction: Loss aversion predicts that risk-averse personssuch as $F 2$-tend to assign too much weight to events that have a low probability of occurrence, when the consequences of such events are extremely adverse.

Non-arm's length judgment proofing, on the other hand, is more likely to occur. Because $F 1$ and $F 2$ are related companies, and therefore may be part of the same consolidated tax group, a sale-leaseback between them will not be subject to federal taxation. Furthermore, F3's motivation for judgment proofing $F 1$ would be to avoid losses from future involuntary claims. Loss aversion predicts that $F 3$ will be more likely to take risks to achieve that goal. However, the legal system historically has responded to these risks through a range of restrictions that tend to discourage non-arm's length judgment proofing. Empirical data suggest that these restrictions are sufficient. Furthermore, where existing law fails as an ex ante deterrent to judgment proofing, it still may have an ex post remedial impact by requiring $F 2$ and $F 3$ to pay $F 1$ 's liabilities. 
Existing constraints on judgment proofing therefore already appear adequate, and the law is likely to evolve additional restrictions as necessary. Accordingly, there is no need to implement radical reform or other regulatory responses. Indeed, to do so could indiscriminately restrict the value creation-"wealth, jobs, incomes, and new products for large numbers of people"270_that comes with business and financial innovation. 271

270. Paul Craig Roberts, Who Did More for Mankind, Mother Teresa or Mike Milken?, Bus. WK., Mar. 2, 1998, at 28 (arguing that creating wealth, jobs, incomes, and new products for large numbers of people is at least as important as redistributing wealth, and referring to arguments to that effect by philosopher David Kelley).

271. The Securities and Exchange Commission in fact recently removed inadvertent regulatory barriers to securitization-the type of business innovation most criticized-in order to "accommodate future innovations in the structured finance market." Investment Company Act Release No. 19105, [1992 Transfer Binder] Fed. Sec. L. Rep. (CCH) If 85,062, at 83,501 (Nov. 19, 1992) (provided in connection with the issuance of Rule 3a-7 under the Investment Company Act of 1940). 
